ARTICLE

Received 9 May 2014 | Accepted 18 Aug 2014 | Published 18 Nov 2014

DOI: $10.1038 /$ ncomms 6012

OPEN

\title{
Improving farming practices reduces the carbon footprint of spring wheat production
}

Yantai Gan ${ }^{1,2}$, Chang Liang ${ }^{3}$, Qiang Chai ${ }^{1}$, Reynald L. Lemke ${ }^{4}$, Con A. Campbell ${ }^{5} \&$ Robert P. Zentner ${ }^{2}$

Wheat is one of the world's most favoured food sources, reaching millions of people on a daily basis. However, its production has climatic consequences. Fuel, inorganic fertilizers and pesticides used in wheat production emit greenhouse gases that can contribute negatively to climate change. It is unknown whether adopting alternative farming practices will increase crop yield while reducing carbon emissions. Here we quantify the carbon footprint of alternative wheat production systems suited to semiarid environments. We find that integrating improved farming practices (that is, fertilizing crops based on soil tests, reducing summerfallow frequencies and rotating cereals with grain legumes) lowers wheat carbon footprint effectively, averaging $-256 \mathrm{~kg} \mathrm{CO}_{2}$ eq ha ${ }^{-1}$ per year. For each $\mathrm{kg}$ of wheat grain produced, a net $0.027-0.377 \mathrm{~kg} \mathrm{CO}$ eq is sequestered into the soil. With the suite of improved farming practices, wheat takes up more $\mathrm{CO}_{2}$ from the atmosphere than is actually emitted during its production.

\footnotetext{
${ }^{1}$ Gansu Provincial Key Laboratory for Aridland Crop Science, Gansu Agricultural University, Lanzhou 730070, China. ${ }^{2}$ Semiarid Prairie Agricultural Research Centre, Agriculture and Agri-Food Canada, Swift Current, Saskatchewan, Canada S9H 3X2. ${ }^{3}$ Pollutant Inventories and Reporting Division, Environment Canada, 9th floor, Fontaine Building, 200 Sacré-Coeur, Gatineau, Québec, Canada K1A OH3. ${ }^{4}$ Saskatoon Research Centre, Agriculture and Agri-Food Canada, Saskatoon, Saskatchewan, Canada S7N 0X2. ${ }^{5}$ Eastern Cereal and Oilseed Research Centre, Agriculture and Agri-Food Canada, 960 Carling Avenue, Ottawa, Ontario, Canada K1A 0C6. Correspondence and requests for materials should be addressed to Y.G. (email: yantai.gan@agr.gc.ca or ganyantai@126.com) or to Q.C. (email: chaiq@gsau.edu.cn).
} 
G lobal demands for major grains such as wheat (Triticum aestivum L.) are projected to increase by $70 \%$ by 2050 (ref. 1), driven by the ever-growing human population's need for food, feed, fibre and fuel ${ }^{2,3}$. To meet this target, grain production must increase substantially, while, at the same time, agriculture,s environmental footprint must shrink dramatically ${ }^{4}$. Given the limited availability of uncultivated land on the planet ${ }^{5}$ and the growing environmental concerns related to converting carbon-rich forests and grasslands to cropland ${ }^{3}$, the future increase in grain production must mostly come from existing farmland 6 .

Wheat is the third largest cereal crop (after maize-Zea Mays, and rice-Oryza sativa) grown on the planet ${ }^{7}$. In semiarid rainfed areas, wheat is traditionally grown in a wheat-fallow or wheatwheat-fallow cropping system ${ }^{8}$. In the fallow year, the land is left unplanted for the entire growing season and multiple operations of tillage are used to control weeds ${ }^{9}$. This farming practice has been used in many arid and semiarid regions of the world, such as Australia $^{10}$, northwest China ${ }^{11}$, northwest Eurasia ${ }^{12}$, central Africa $^{13}$ and the North American prairies. It is believed that summerfallowing allows a large proportion of rainfall to be conserved in the soil profile, which is available for the crops grown in the following year ${ }^{14}$. Also, the soils in the fallow period release nitrogen $(\mathrm{N})$ via $\mathrm{N}$ mineralization of soil organic matter ${ }^{15,16}$, benefiting the crops grown in subsequent years ${ }^{17}$. However, recent evidence has shown that summerfallowing can result in serious environmental consequences ${ }^{18,19}$, as more fossil fuel is required for the multiple tillage operations during the fallow period ${ }^{19}$. Also, soil organic matter can be depleted with a higher frequency of fallowing ${ }^{20}$, causing the degradation of soil quality and increased soil erosion ${ }^{18}$.

The adoption of more intensified cropping systems (for example, reducing the frequency of summerfallow, including legumes in the rotation, use of higher inputs of inorganic fertilizers and chemicals) has been shown to increase crop yields compared with traditional fallow-wheat or wheat monoculture systems $^{21}$. However, the increased use of inorganic fertilizers and pesticides in high-yielding systems increases greenhouse gas emissions $^{22,23}$. Also, there is growing evidence of yield plateaus or abrupt decreases in the rate of yield gain over years ${ }^{24}$. In some areas, crop yields have either stagnated or even collapsed in recent years ${ }^{25}$. This evidence clearly indicates that the high-yielding systems can also have negative climate consequences. It is unclear whether some individual farming practices that have been proven to be essential and successful in crop production can be packaged together in a systematic manner to empower the increase of crop yields, while, at the same time, reducing the potentially negative impacts on the environment.

Here we identify the following four key farming practices and integrate them systematically into alternative wheat production systems: (i) inclusion of grain legumes in rotations to fix atmospheric $\mathrm{N}_{2}$ into plant-available $\mathrm{N}$ and to replace a portion of inorganic $\mathrm{N}$ fertilizer in wheat production; (ii) use of annual soil tests to determine soil residual nutrients and potential mineralized $\mathrm{N}$ from soil organic matter that may be available for crops, (iii) application of a proper rate of inorganic fertilizers to meet the nutrient requirements by crops and to avoid over- or under-fertilization and (iv) adoption of more intensified crop rotation systems (that is, cropping with reduced frequency of summerfallowing) so as to sequester greater amounts of $\mathrm{CO}_{2}$ from the atmosphere to offset carbon emissions associated with crop production inputs. We quantify the climate consequences associated with the adoption of a suite of improved farming practices in alternative wheat production systems. Two metrics of carbon footprints are determined: first, the quantity of greenhouse gases emitted per unit of farmland (for the purpose of simplicity, it is defined as per-area carbon footprint), and second, the quantity of greenhouse gases associated with per $\mathrm{kg}$ of grain produced (defined as per-yield carbon footprint). Our central hypothesis is that the packaging together of these individually proven farming practices can increase crop yields, enhance net carbon sequestration and lower the carbon footprint of wheat production. We test the hypothesis using a 25-year (1985-2009) field experiment conducted at the Agriculture and Agri-Food Canada Research Centre, Swift Current, Saskatchewan, Canada. We find that spring wheat produced using the suite of improved farming practices has negative (more desirable) carbon footprints, averaging $-256 \mathrm{~kg} \mathrm{CO}_{2} \mathrm{eq} \mathrm{ha}^{-1}$ per year. For each $\mathrm{kg}$ of wheat grain produced, a net $0.027-0.377 \mathrm{~kg} \mathrm{CO}_{2}$ eq is sequestered into the soil. Among factors, the choice of cropping systems has the highest impact on the carbon footprint of wheat production, with the lentil-wheat (LentW) rotation system having the lowest perarea carbon footprint at $-552 \mathrm{~kg} \mathrm{CO}_{2}$ eq ha ${ }^{-1}$ and the most negative per-yield carbon footprint at $-0.377 \mathrm{~kg} \mathrm{CO}_{2}$ eq per $\mathrm{kg}$ of grain. We conclude that wheat can convert more $\mathrm{CO}_{2}$ from the atmosphere into soil carbon than is actually emitted during its production if some key farming practices can be identified and integrated together systematically.

\section{Results}

Carbon footprints of wheat per area and per kg of grain. Spring wheat produced using the suite of farming practices (described

Table 1 | Carbon footprints of spring wheat on the basis of per area and per unit of grain yield.

\begin{tabular}{|c|c|c|c|c|c|c|c|c|}
\hline \multirow[t]{3}{*}{ Cropping system ${ }^{\star}$} & \multicolumn{4}{|c|}{ Per-area carbon footprint } & \multicolumn{4}{|c|}{ Per-yield carbon footprint } \\
\hline & Dry $^{\dagger}$ & Normal $^{\dagger}$ & Wet $^{\dagger}$ & Mean & Dry & Normal & Wet & Mean \\
\hline & \multicolumn{4}{|c|}{$\mathrm{kg} \mathrm{CO}_{2}$ eq ha ${ }^{-1}$ per year } & \multicolumn{4}{|c|}{$\mathrm{kg} \mathrm{CO}_{2}$ eq kg $\mathrm{kg}^{-1}$ of grain per year } \\
\hline FWW & -116 & -254 & -233 & -218 & -0.168 & -0.166 & -0.109 & -0.164 \\
\hline ContW & -137 & -304 & -265 & -243 & -0.148 & -0.167 & -0.154 & -0.151 \\
\hline LentW & -379 & -634 & -580 & -552 & -0.570 & -0.322 & -0.249 & -0.377 \\
\hline$P$-value & $<0.01$ & $<0.01$ & $<0.01$ & $<0.01$ & 0.02 & $<0.01$ & $<0.01$ & $<0.01$ \\
\hline
\end{tabular}

LS-mean, least-square mean; LSD, least significant difference.

${ }^{\star}$ The four rotation systems are: (i) fallow-flax (Linum usitatissimum)-wheat (FFlxW), (ii) fallow-wheat-wheat (FWW), (iii) continuous wheat (ContW) and (iv) lentil (Lens culinaris Medikus)-wheat (LentW).

$\dagger$ Dry years with annual precipitation $(\mathrm{Pr})$ below $210 \mathrm{~mm}$ and the ratio of $\mathrm{Pr}$ to evapotranspiration $(\mathrm{Pr} / \mathrm{PE})=0.291$; normal years with annual $\mathrm{Pr}$ between 211 and $340 \mathrm{~mm}$ and $\mathrm{Pr} / \mathrm{PE}=0.495$ and wet years with annual $\operatorname{Pr}$ between 341 and $420 \mathrm{~mm}$ and $\mathrm{Pr} / \mathrm{PE}=0.687$.

$\ddagger L S D$ between the four rotation systems determined using mixed effect model $(n=3 \times 7,3 \times 13$ and $3 \times 5$ in dry, normal and wet years, respectively). 
above) had negative (more desirable) carbon footprints, both on the basis of per unit of farmland and per $\mathrm{kg}$ of grain yield (Table 1). The 25 study years (1985-2009) were categorized into three groups based on water availability: 7 dry years with annual precipitation (Pr) below $210 \mathrm{~mm}$ and the ratio of Pr to evapotranspiration $(\mathrm{Pr} / \mathrm{PE})=0.291 ; 13$ normal years with annual $\mathrm{Pr}$ between 211 and $340 \mathrm{~mm}$ and $\mathrm{Pr} / \mathrm{PE}=0.495$ and 5 wet years with annual $\operatorname{Pr}$ between 341 and $420 \mathrm{~mm}$ and $\operatorname{Pr} / \mathrm{PE}=0.687$. Negative carbon footprint values were consistently attained in each of the three water-availability categories. Average annual per-area carbon footprint was $-165 \mathrm{~kg} \mathrm{CO}_{2} \mathrm{eq} \mathrm{ha}^{-1}$ in dry years, -323 in normal years and -274 in wet years. The negative carbon footprints indicate that the production of spring wheat on the semiarid North American prairies sequesters more $\mathrm{CO}_{2}$ from the atmosphere than is emitted, and that spring wheat produced with improved farming practices can act as a net sink of $\mathrm{CO}_{2}$. Four cropping systems were evaluated in this study, namely (i) fallow-flax-wheat (FFlxW), (ii) fallow-wheat-wheat (FWW), (iii) continuous wheat (ContW) and (iv) LentW. Among these, the LentW system had the lowest per-area carbon footprint at $-552 \mathrm{~kg} \mathrm{CO}_{2}$ eq ha ${ }^{-1}$, which was $127 \%$ lower than the ContW system, 153\% lower than FWW and 790\% lower than FFlxW. The largest negative per-area carbon footprint for the LentW system was due to the lower rates of $\mathrm{N}$ fertilizer required by the wheat crop in this rotation, as the preceding lentil plants fixed $\mathrm{N}_{2}$ from the atmosphere through its biological association with soil microorganisms thereby building up the soil's $\mathrm{N}$ supplying capacity (more discussion below).

Similarly, when calculated on the basis of per $\mathrm{kg}$ of grain yield, wheat cropping systems had negative per-yield carbon footprints, averaging $-0.223 \mathrm{~kg} \mathrm{CO}_{2}$ eq per $\mathrm{kg}$ of grain in dry years, -0.176 in normal years and -0.129 in wet years (Table 1). These negative per-yield carbon footprint values indicated that for each $\mathrm{kg}$ of wheat grain produced a net amount of $0.027-0.377 \mathrm{~kg}$ of $\mathrm{CO}_{2}$ eq was captured from the atmosphere across all water availability levels. Among the four cropping systems, the LentW rotation was again most favourable with the most negative peryield carbon footprint at $-0.377 \mathrm{~kg} \mathrm{CO}$ eq per $\mathrm{kg}$ of grain per year, followed by the ContW system at -0.151 and FWW at -0.164 , and FFlxW at -0.027 being the least favourable.

To determine the key factors that contribute to the negative carbon footprint and their relative magnitudes in influencing the carbon footprint values, we used analysis of covariance and found that about $82 \%$ of the variation in per-area carbon footprint values was due to differences in the cropping systems (Supplementary Table 1). Soil organic carbon was the second largest contributor $(4.4 \%)$ to the variation of per-area carbon footprint values. In a more or less similar manner, about $61 \%$ of the variation in per-yield carbon footprint was due to differences in the cropping systems, and the second largest contributor to the variation (14.6\%) was grain yield. Nitrogen fertilization contributed $6.2 \%$ to the variation of per-yield carbon footprint, with the rest of the factors contributing little or none. Here we show that the choice of cropping system in which wheat crops are produced has significant climate consequences, and that the key to lowering the carbon footprint of wheat cropping is the development and adoption of cropping systems with individually proven farming practices integrated together.

The analysis of covariance also revealed significant interactions among some of the crop input factors that influenced carbon footprints (Supplementary Table 1); this suggests that the change of one input factor may impact how the other factors affect the carbon footprint values (sensitivity tests described below provide more insights). However, the analysis of covariance across the three water-availability categories showed that the choice of cropping systems, soil carbon change over time, fertilizer $\mathrm{N}$ input and grain yield were the four most important factors influencing the carbon footprint values in wheat cropping. Therefore, more in-depth analyses were conducted for these key factors.

Soil organic carbon and wheat carbon footprints. The base value of soil organic carbon (SOC) measured in 1979 when the LentW system was first introduced was about $33 \mathrm{MgCha}^{-1}$. Since then, the SOC under these wheat cropping systems has increased gradually, with the greatest increase occurring between 1993 and 1999 (Fig. 1). The larger gain of SOC during the latter period was due to higher crop productivity ${ }^{26}$ with more biomass carbon returned to the soil ${ }^{27}$. This was accomplished primarily through the higher rates of $\mathrm{N}$ fertilizer applied to the crops (with the new soil test recommendation guidelines) coupled with more favourable growing season precipitation in this period. Wellmanaged cropping systems have been shown to sequester more carbon $^{28}$ with crop residue retention serving as a key factor increasing the quantity of $\mathrm{SOC}^{29}$.

A per unit farmland carbon footprint value represents the balance between carbon emissions and carbon sequestration. Averaged over the 25-year study period, the annual greenhouse gas emissions averaged $357 \mathrm{~kg} \mathrm{CO}_{2}$ eq ha ${ }^{-1}$ in dry years, 577 in normal years and 687 in wet years (Fig. 2, top portion). The emissions included those from crop residue decomposition, applied inorganic $\mathrm{N}$ and phosphorus fertilizers, $\mathrm{N}$ leaching losses, application of pesticides, fuel used in various farming operations (such as planting, spraying pesticides, harvesting and so on); and fossil energy used during the manufacture, transportation, storage and delivery of these crop inputs to the farm gate. However, these emissions were more than offset by the greater carbon conversion of wheat plants from atmospheric $\mathrm{CO}_{2}$ into plant biomass and ultimately sequestered into the soil (Fig. 2, bottom portion). Consequently, the carbon footprints per unit of farmland became negative (Table 1).

Weather played a significant role in affecting both carbon emissions and carbon sequestration. There was a generally lower carbon emission in drier years because of less production inputs to the crops and lower $\mathrm{N}_{2} \mathrm{O}$ emissions from crop residue decomposition compared with the other years (Fig. 2), whereas in normal and wetter years, more plant biomass carbon was sequestered to the soil. On average, annual soil carbon gain was $877 \pm 15 \mathrm{~kg} \mathrm{CO}_{2} \mathrm{eq} \mathrm{ha}^{-1}$ in normal years and $961 \pm 14$ in wet years, which were $69 \%$ and $85 \%$ more, respectively, than the soil

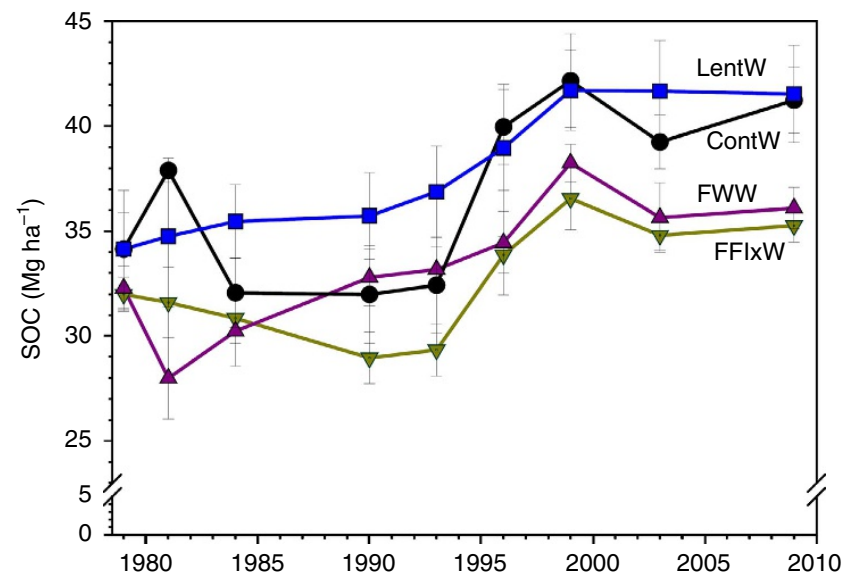

Figure 1 | Soil organic carbon in 0-15 cm depth under four cropping systems. The rotation systems are: fallow-flax-wheat (FFlxW), fallowwheat-wheat (FWW), continuous wheat (ContW) and lentil-wheat (LentW). The line bars are the standard error of the means. Data are for the period 1979-2009. 


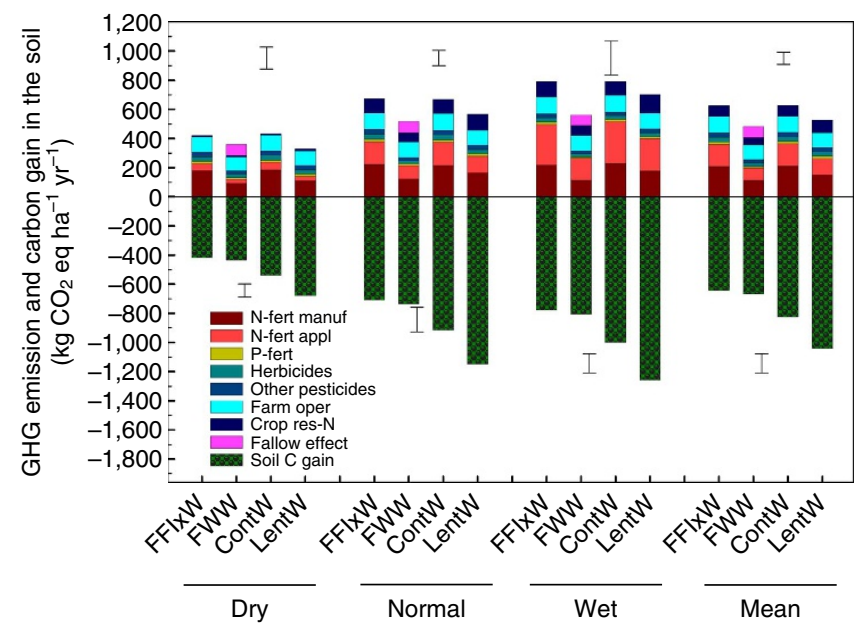

Figure 2 | Carbon emissions (top) and sequestrations (bottom) for alternative wheat cropping systems. These rotation systems were tested under dry (the ratio of precipitation to evapotranspiration $(\mathrm{Pr} / \mathrm{PE})=0.291 \pm 0.014)$, normal $(\mathrm{Pr} / \mathrm{PE}=0.496 \pm 0.024)$ and wet $(\mathrm{Pr} / \mathrm{PE}=0.688 \pm 0.036)$ growing conditions. The line bars are least significant differences (LSDs) with $P \leq 0.05$ among the four rotation systems within each water-availability category ( $n=3$ replicates $\times 7$ years for dry years, $3 \times 13$ for normal years and $3 \times 5$ for wet years).

carbon gain obtained in dry years. Greater crop productivity under more favourable weather conditions ${ }^{27}$ leads to greater crop residue and root biomass production ${ }^{30}$, which helps enhance soil organic carbon.

Among the four cropping systems, the LentW system gained an average $1,039 \mathrm{~kg} \mathrm{CO}_{2} \mathrm{eq} \mathrm{ha}^{-1}$ annually through soil carbon sequestration, which was $26 \%$ more than the gain for ContW, $56 \%$ more than for FWW and $62 \%$ more than for FFlxW. This cereal-legume rotation had the advantage that the lentil plants fixed $\mathrm{N}_{2}$ from the atmosphere ${ }^{31}$, and the increased $\mathrm{N}$ availability enhanced plant biomass accumulation ${ }^{26}$. Despite the large variation in carbon emissions and sequestration between the four systems (Fig. 2), the overall ranking of their carbon footprint values was consistent across the dry, normal and wet growing conditions (Table 1). This suggests that spring wheat grown using this suite of improved farming practices can attain a net carbon balance regardless of water availability (except for years with extremely dry weather).

The SOC level has shown little further change since 1999 (Fig. 1). Coincidentally, crop yields have been in a stagnate state or trending lower since the beginning of the 2000s (Fig. 3a). On average, annual wheat grain yield in the 2000s was $17 \%$ lower $(P<0.01)$ than the yield obtained in the 1990s (Fig. 3b). Crops received about $10 \%$ less precipitation during the growing seasons of the 2000s than in the 1990s. In semiarid areas, water availability is key for crop productivity ${ }^{32,33}$.

Calculated by year, the wheat carbon footprint was primarily in the negative territory during the entire 25 study years, and the values in the earlier years were generally more negative (with greater variation) compared with the other years (Fig. 3c). Calculated by decade, the annual mean value of per-area carbon footprint in the $1980 \mathrm{~s}$ was $-181 \pm 12 \mathrm{~kg} \mathrm{CO}_{2}$ eq ha ${ }^{-1}$, significantly lower than those obtained in the 1990s and 2000s (Fig. 3d); similarly, the mean value of per-yield carbon footprint in the 1980s was also lower than those obtained in the 1990s and 2000s. However, the carbon footprint values obtained in the 1990 s did not differ from those in the 2000s, even though overall crop yield has been trending lower in recent years (Fig. 3a). In this context, it is clear that the wheat carbon footprint is an outcome of a complex of various factors, including the change in SOC, the quantity and method of crop inputs, the crop yield response and other relevant factors (sensitivity tests below provide more insights).

The quantity and method of crop inputs and carbon footprints. Over the 25 -year period, annual wheat grain yield varied from 201 to $3,484 \mathrm{~kg} \mathrm{ha}^{-1}$ (Table 2), mainly reflecting the level of growing season precipitation, with each millimetre of precipitation increasing grain yield by an average of $21.4 \mathrm{~kg} \mathrm{ha}^{-1}$ (Fig. 4a). There was a significant interaction between water availability and cropping systems in affecting grain yield. The four systems had a similar level of grain yield in dry years, whereas wheat in the FWW system produced significantly lower grain yields in the normal (24\% lower) and wet (27\% lower) years than the other systems (Table 2). Summerfallow occupies one-third of the rotation phases in the FWW system, resulting in the low annualized wheat yield over the 3 -year rotation phases.

In each of the 25 individual years, wheat was fertilized based on annual soil tests ${ }^{34}$, which varied among the crop rotation systems and between years (Table 2). Among the four cropping systems, FWW received the lowest quantity of $\mathrm{N}$ fertilizer because no fertilizer was needed in the fallow phase, whereas the ContW system received the highest quantity of $\mathrm{N}$ fertilizer, giving rise to the lowest fertilizer $\mathrm{N}$ use efficiency (defined as the $\mathrm{kg}$ grain produced per $\mathrm{kg}$ of fertilizer-N applied). Nevertheless, the fertilization of wheat crops based on annual soil tests permits a best estimate between $\mathrm{N}$ supplies and $\mathrm{N}$ requirements by the crops. Consequently, $\mathrm{N}$ surplus (defined as $\mathrm{N}$ input minus total $\mathrm{N}$ uptake by crop plants, with the assumption of soil $\mathrm{N}$ state remaining unchanged in a given crop season ${ }^{35}$ ) was near zero in most years (Fig. 4b). When the above-ground $\mathrm{N}$ surplus is equal to or smaller than zero, yield-scaled carbon emissions typically remain small ${ }^{35}$. These results suggest that the amount of $\mathrm{N}$ fertilizer applied to the crops in this long-term experiment is adequate in meeting the $\mathrm{N}$ requirements for normal plant growth, whereas minimizing carbon emissions associated with $\mathrm{N}$ input.

There was a positive relationship between $\mathrm{N}$ fertilizer input and carbon emissions, with each $\mathrm{kg}$ of $\mathrm{N}$ input giving rise to $8.29 \mathrm{~kg}$ $\mathrm{CO}_{2}$ eq ha ${ }^{-1}$ of emissions (Fig. 4c). This is no surprise as inorganic $\mathrm{N}$ fertilizers contributed the greatest percentage of total emissions ascribed to the crop inputs (Supplementary Table 2). On average, $53 \%$ of the $\mathrm{C}$ emissions came from $\mathrm{N}$ sources, of which $22 \%$ came from direct $\mathrm{N}_{2} \mathrm{O}$ emissions and indirect $\mathrm{N}_{2} \mathrm{O}$ emissions via volatilization of $\mathrm{NH}_{3}$ and $\mathrm{NOx}$ and leaching of nitrate from the application of $\mathrm{N}$ fertilizers in the field, and the other $31 \%$ came from the manufacture, transportation, storage and delivery of $\mathrm{N}$ fertilizers to farm gates before farm use. The contribution of $\mathrm{N}$ fertilizer to total $\mathrm{C}$ emissions was 16.7 times that of $\mathrm{P}$ fertilizer, 8.4 times that of pesticides and 2.3 times that of the various on-farm cultural and tillage operations. These numbers are in the range of the values reported from the other semiarid wheat production areas with comparable systems, such as the North American prairies ${ }^{36-38}$, Finland ${ }^{39}$, New South Wales of Australia ${ }^{40}$, the United Kingdom ${ }^{41}$ and the northern China Plains ${ }^{42}$.

A closer examination of the relationship between $\mathrm{N}$ supply and $\mathrm{N}$ uptake revealed that fertilizer- $\mathrm{N}$ contributed a portion of the $\mathrm{N}$ in the harvested grain and straw, with the remaining $\mathrm{N}$ uptake coming from residual soil $\mathrm{N}$ and $\mathrm{N}$ mineralized from soil organic matter during the growing season (data not shown). In semiarid climates, soil-sourced $\mathrm{N}$, mostly through the released inorganic $\mathrm{N}$ from $\mathrm{N}$ mineralization ${ }^{43}$, contributes a large portion of the $\mathrm{N}$ uptake by crops ${ }^{44}$. Here we show that use of annual soil tests to quantify $\mathrm{N}$ fertilizer requirements of crops is a simple and key 

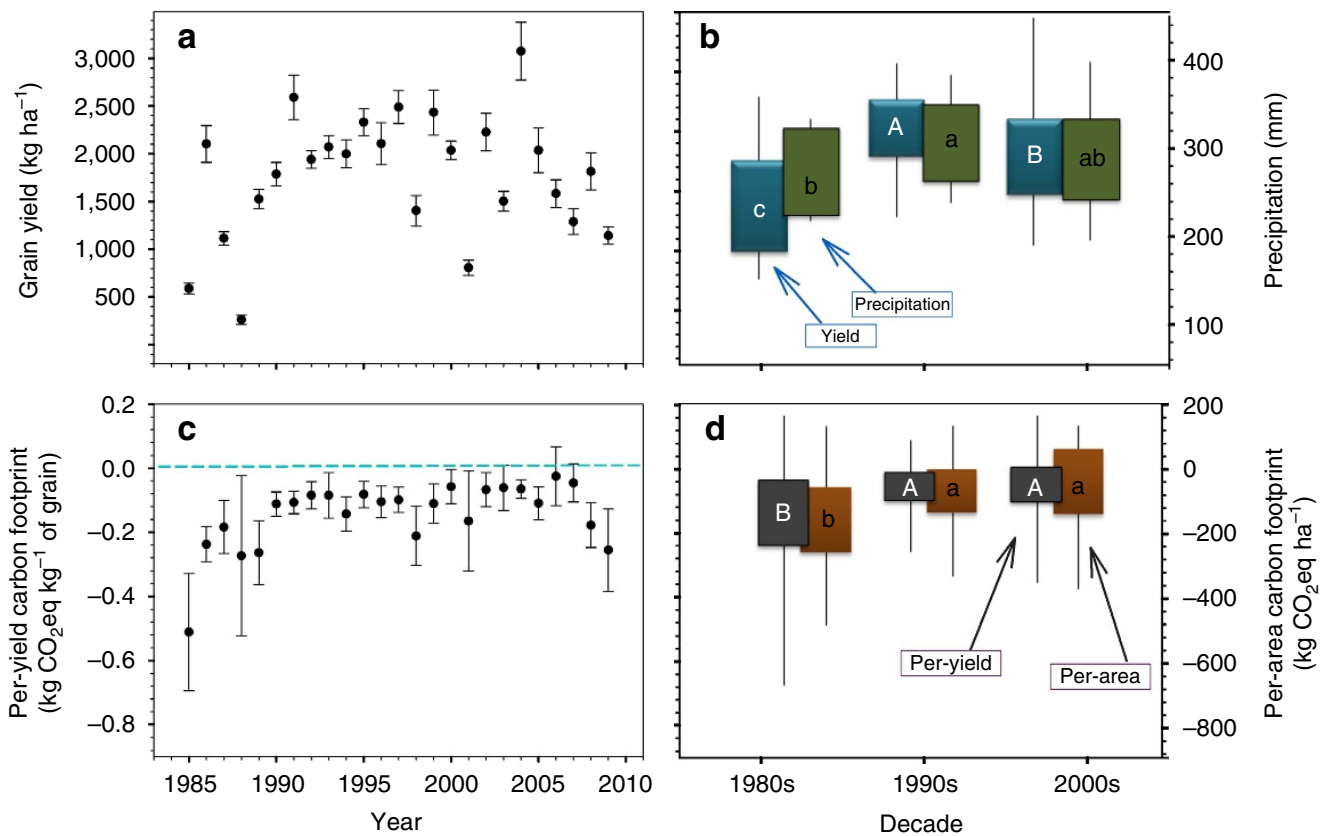

Figure 3 | Grain yield and carbon footprints of spring wheat in different years or decades. (a) Grain yield in year; (b) grain yield and growing-season precipitation in each decade; (c) carbon footprint values in each year and (d) carbon footprints per-area and per-yield in each decade. The line bars in a and c are confidence intervals at $95 \%$. In $\mathbf{b}$ and $\mathbf{d}$, the length of the line bars represents the maximum and minimum values, and the height of the boxes represents the upper and lower quartiles. The boxes with uppercase letters denote significant differences $(P<0.05)$ between the three decades in $(\mathbf{b})$ grain yield or (d) per-yield carbon footprint, and the boxes with lowercase letters denote significant differences $(P<0.05)$ between the three decades in

(b) precipitation or (d) in per-area carbon footprint.

Table 2 | Wheat grain yield and its relation to fertilizer-N input and NUE.

\begin{tabular}{|c|c|c|c|c|c|c|}
\hline \multirow[t]{3}{*}{ Water availability } & \multirow[t]{3}{*}{ Cropping system $^{\star}$} & \multicolumn{3}{|c|}{ Grain yield } & \multirow{2}{*}{$\frac{\text { N fertilizer }}{\text { Mean }^{\dagger}}$} & \multirow{2}{*}{$\frac{\text { NUE }}{\text { Mean }^{\dagger}}$} \\
\hline & & Mean ${ }^{\dagger}$ & Min & Max & & \\
\hline & & \multicolumn{3}{|c|}{ kg ha $^{-1}$} & kgha $^{-1}$ & kg grain $\mathrm{kg}^{-1}$ of $\mathrm{N}$ \\
\hline \multirow[t]{6}{*}{ Dry } & FFIxW & 1,119 & 226 & 1,879 & 37.3 & 63.4 \\
\hline & FWW & 976 & 405 & 1,499 & 19.6 & 60.9 \\
\hline & ContW & 1,086 & 201 & 1,712 & 38.7 & 40.8 \\
\hline & LentW & 1,021 & 218 & 2,063 & 22.9 & 73.6 \\
\hline & LSD $(0.05)^{\ddagger}$ & 212 & - & - & - & 37.4 \\
\hline & $P$-value & 0.15 & - & - & - & 0.34 \\
\hline \multirow[t]{6}{*}{ Normal } & FFIxW & 2,124 & 952 & 3,493 & 46.5 & 76.6 \\
\hline & FWW & 1,604 & 1,221 & 2,200 & 26.2 & 77.5 \\
\hline & ContW & 2,054 & 982 & 3,130 & 45.5 & 63.9 \\
\hline & LentW & 2,180 & 1,040 & 3,484 & 34.1 & 126.0 \\
\hline & $\operatorname{LSD}(0.05)^{\ddagger}$ & 205 & - & - & - & 48.7 \\
\hline & $P$-value & $<0.01$ & - & - & - & 0.04 \\
\hline \multirow[t]{6}{*}{ Wet } & FFIxW & 2,458 & 2,186 & 2,923 & 45.6 & 61.0 \\
\hline & FWW & 1,735 & 1,402 & 1,937 & 24.1 & 77.0 \\
\hline & ContW & 2,248 & 1,566 & 2,917 & 48.1 & 47.9 \\
\hline & LentW & 2,389 & 2,104 & 2,594 & 37.0 & 65.2 \\
\hline & $\operatorname{LSD}(0.05)^{\ddagger}$ & 243 & - & - & - & 27.6 \\
\hline & $P$-value & 0.03 & - & - & - & 0.03 \\
\hline \multirow[t]{6}{*}{ Mean } & FFIxW & 1,909 & 226 & 3,493 & 43.7 & 69.8 \\
\hline & FWW & 1,455 & 405 & 2,200 & 23.9 & 72.8 \\
\hline & ContW & 1,822 & 201 & 3,130 & 44.1 & 54.2 \\
\hline & LentW & 1,897 & 218 & 3,484 & 31.5 & 99.1 \\
\hline & LSD $(0.05)^{\ddagger}$ & 138 & - & - & - & 27.3 \\
\hline & $P$-value & $<0.01$ & - & - & - & $<0.01$ \\
\hline
\end{tabular}



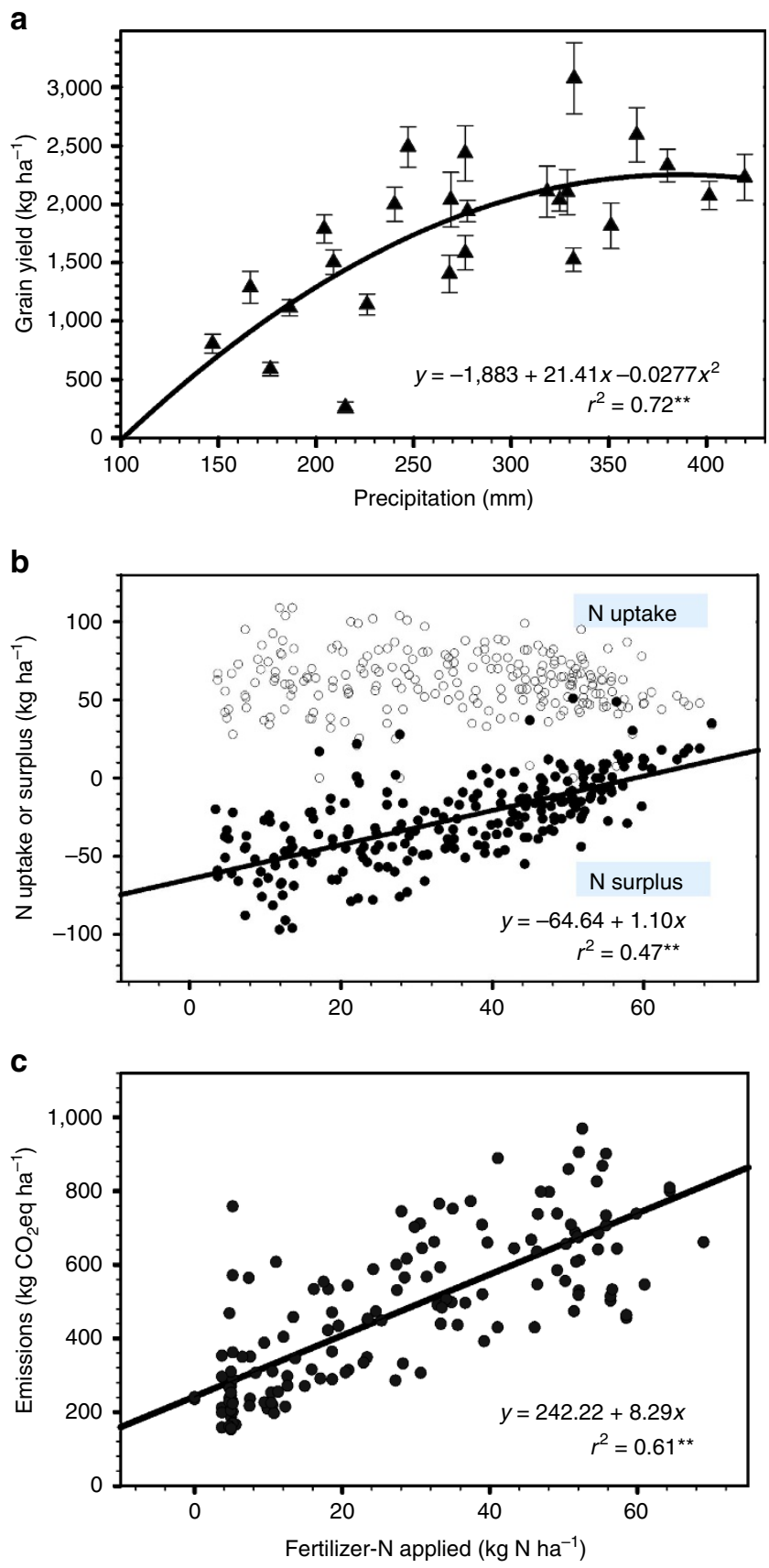

Figure 4 | Effects of precipitation and $\mathbf{N}$ input on wheat grain yield and carbon emissions. (a) Wheat grain yield is a quadratic function of the growing-season precipitation during the 25-year period (the line bars are the standard error of the means); (b) increasing fertilizer- $\mathrm{N}$ input in wheat production increases the amount of $\mathrm{N}$-surplus in the soil (solid circles) in a linear relationship, whereas $\mathrm{N}$ input has no effect on $\mathrm{N}$ uptake in the aboveground plant parts (open circles) and (c) increasing fertilizer- $\mathrm{N}$ input increases carbon emissions and each $\mathrm{kg}$ of $\mathrm{N}$ increases emissions by $8.29 \mathrm{~kg} \mathrm{CO}$ equivalents.

practice to ensure a proper nutrient balance between supplies and requirements of crops, to avoid over- and under-fertilization in crop production, and to lower the carbon footprint of crop production.

Legume-cereal rotations and carbon footprints. Lentil was rotated with wheat in alternate years, a cropping system in which the grain legume was used to partially replace the fallow phase in fallow-wheat or FWW systems or to diversify the wheat monoculture system. This was considered an alternative and more desirable system compared with the traditional rotation systems. On average, wheat in the LentW system produced a similar amount of grain as in the ContW system, averaging $1,860 \pm 150 \mathrm{~kg} \mathrm{ha}^{-1}$ per year, but the former did so with $29 \%$ less $\mathrm{N}$ fertilizer (Table 2). Consequently, fertilizer $\mathrm{N}$ use efficiency for wheat in the LentW system averaged $80 \%$ greater than for ContW in dry years, $97 \%$ greater in normal years and $36 \%$ greater in wet years. Legume-rhizobial associations are known to be an effective solar-driven $\mathrm{N}_{2}$-fixing system in which atmospheric $\mathrm{N}_{2}$ is transformed into ammonia to provide a large portion of the $\mathrm{N}$ requirements for plant growth ${ }^{31}$. A portion of the fixed- $N$ remains in the crop roots, nodules and in the soil rhizodeposits contributing to the $\mathrm{N}$ pools in the soil and benefiting subsequent crops $^{30,31,45}$. Although lentil crops usually have a lower aboveground biomass than wheat $\operatorname{crops}^{30}$, the higher $\mathrm{N}$ concentration in lentil residues provides greater $\mathrm{N}$-benefits to subsequent crops ${ }^{46}$. It is clear that the use of grain legumes to replace the summerfallow phase of the rotation is one of the key components for obtaining a reduced or negative carbon footprint in wheat cropping.

Sensitivity of carbon footprints to key contributing factors. An important question is how sensitive is the carbon footprint value to the key contributing factors. To assess this, we conduct three sensitivity tests: one is to test how sensitive the carbon footprint values are in response to the gain or loss of soil organic carbon over time; the second is to determine the sensitivity of $\mathrm{N}_{2} \mathrm{O}$ emission profiles and the resulting carbon footprints to the methods of $\mathrm{N}$ fertilizer application; and the third is to test whether the carbon footprint values differ with the calculations at the 100 - versus 20 -year timeframes of global warming potential for $\mathrm{N}_{2} \mathrm{O}$. These sensitivity tests may provide some insights into the usefulness of the results obtained from this long-term experiment to other regions with environmental conditions similar to those on the North American prairies. Also, these tests may shed some light on the longer- versus shorter-term benefits of the net $\mathrm{C}$ sequestering farming practices for policy relevance.

In the first sensitivity test, we found that the gain in SOC over time played a significant role in offsetting carbon emissions ascribed to crop inputs and ultimately impacting the carbon footprint values in this study (Fig. 2, Table 3). Wheat carbon footprint was a linear function of the quantity of SOC gains, with each $\mathrm{kg}$ of soil carbon gain lowering the carbon footprint values by $0.0003 \mathrm{U}$ (Fig. 5a). During the 25 -year period, the soils under these four rotation systems gained SOC equivalent to an amount of $787 \mathrm{CO}_{2}$ eq ha ${ }^{-1}$ per year (ranging from 310 to $1,280 \mathrm{CO}_{2}$ eq ha ${ }^{-1}$ per year). The sensitivity test reveals that a gain of SOC at an amount of $454 \mathrm{CO}_{2}$ eq ha ${ }^{-1}$ per year or more can result in negative carbon footprints. In other words, a $42 \%$ decrease of SOC gain from the current level of the gain measured in the longterm experiment (that is, decrease the SOC gain from 787 to 454 $\mathrm{CO}_{2}$ eq ha ${ }^{-1}$ per year) would be the 'breakeven' point (that is, the production of wheat becomes carbon neutral). Conversely, with a hypothetic increase of SOC gain by another $25 \%$ from the current level of gain (that is, from the current average gain of 787 to a hypothetic gain of $983 \mathrm{CO}_{2}$ eq ha ${ }^{-1}$ per year), the carbon footprint value would become $77 \%$ more negative than those estimated in the present study. Noteworthy is that the carbon footprint values did not have a clear correlation with grain yields (Fig. 5b), even though grain yields served as the denominator in the calculation of carbon footprint values. This suggests that the carbon footprint of wheat production is an outcome of a complex of various factors, with SOC serving as one of them 
Table 3 | Sensitivity of carbon footprints to the method of $\mathbf{N}$ application and the timeframe of global warming potential.

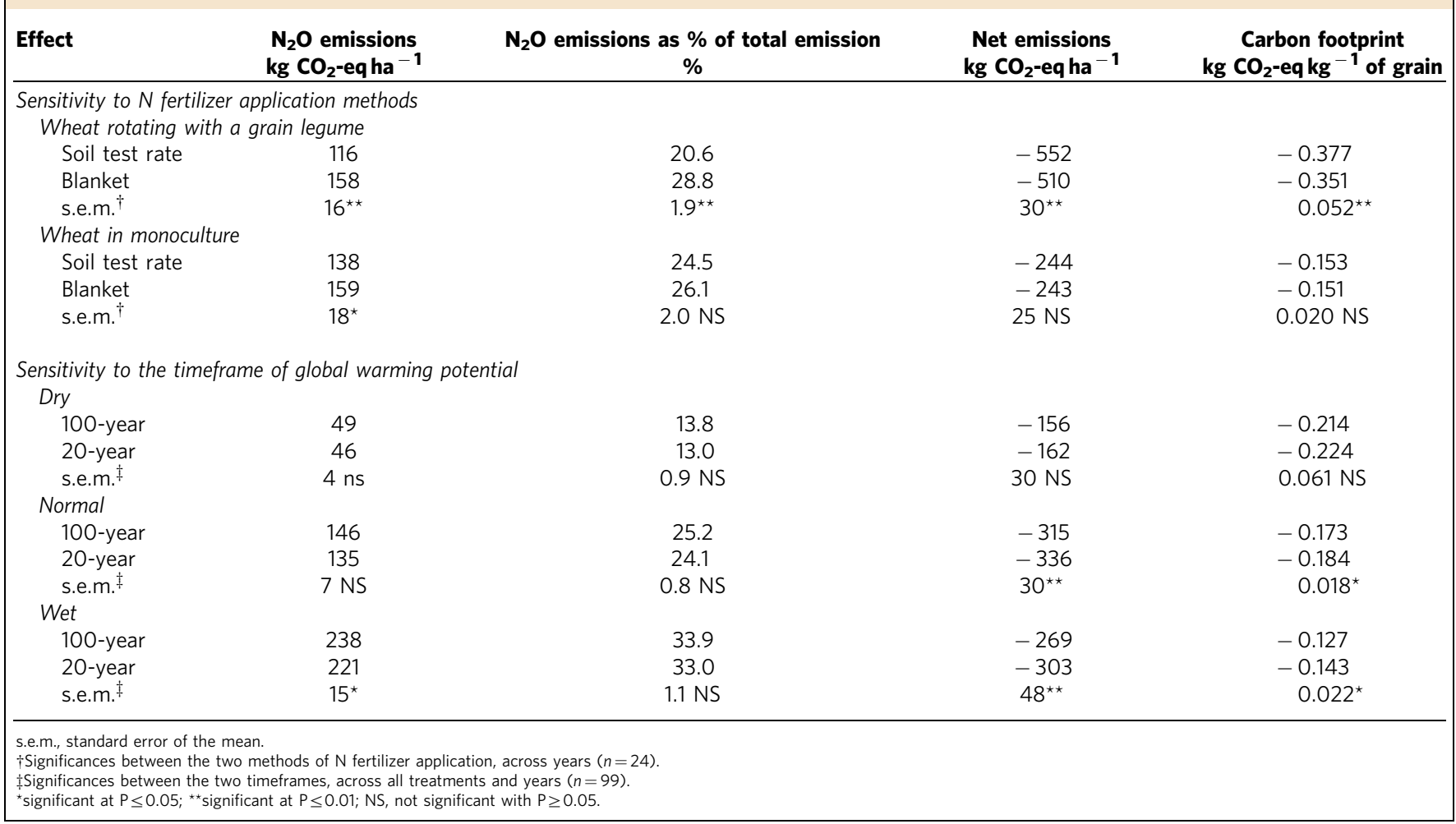

(more discussion on the effect of SOC on carbon footprints is provided in the Discussion section below).

Wheat crops were fertilized on the basis of annual soil tests, with the annual $\mathrm{N}$ fertilizer rate varying from 3.7 to $69 \mathrm{~kg} \mathrm{~N} \mathrm{ha}^{-1}$; this is equivalent to an average $\mathrm{N}$ fertilizer rate of $44.1 \mathrm{~kg} \mathrm{~N}$ ha $^{-1}$ per year. In the second sensitivity test, we chose two of the crop rotation systems to illustrate whether the methods of $\mathrm{N}$ fertilization would have had an impact on carbon emission profiles and the carbon footprints (Table 3). For the legumecereal rotation, the sensitivity test showed that the $\mathrm{N}_{2} \mathrm{O}$ emission was $116 \mathrm{~kg} \mathrm{CO}_{2}$ eq ha ${ }^{-1}$ with $\mathrm{N}$ fertilizer application based on annual soil tests, whereas the $\mathrm{N}_{2} \mathrm{O}$ emission value was increased to $158 \mathrm{~kg} \mathrm{CO}_{2}$ eq ha $^{-1}$ if a blanket rate of $44.1 \mathrm{~kg} \mathrm{~N}$ per ha had been otherwise used without soil tests. The former approach reduced $\mathrm{N}_{2} \mathrm{O}$ emissions by $27 \%$ annually compared with the latter. As a result, the soil-testing approach lowered the annual carbon footprint of wheat by an average of 7\%. Similarly, when the two different $\mathrm{N}$ fertilization approaches were compared for the wheat monoculture system (that is, ContW system), the soiltesting approach reduced the $\mathrm{N}_{2} \mathrm{O}$ emissions by an average of $13 \%$ as compared with a blanket $\mathrm{N}$ application. Between the two crop rotation systems (with the soil-testing approach), the LentW system decreased the $\mathrm{N}_{2} \mathrm{O}$ emissions by an average of $16 \%$, reduced total emissions by $127 \%$ and lowered the carbon footprints by $150 \%$, compared with the wheat monoculture system. These results clearly indicate (i) the benefits of soil testing for crop fertilization over a blanket rate of fertilization and (ii) the benefits of using legume-cereal rotation over wheat monoculture systems, in reducing carbon emissions and lowering carbon footprints.

The library parameters and impact assessment used in the carbon footprint calculation in the scientific communities are primarily based on the international standards of $1 \mathrm{~kg}$ of $\mathrm{N}_{2} \mathrm{O}$ having the global warming potential of $298 \mathrm{CO}_{2}$ equivalents with a 100 -year timeframe ${ }^{47}$. However, to understand whether the
$\mathrm{N}_{2} \mathrm{O}$ emissions and the net $\mathrm{C}$ sequestering found in this study might differ with the change of the timeframe of global warming potential for $\mathrm{N}_{2} \mathrm{O}$, we conducted the third sensitivity test to determine the footprint sensitivity in response to the 100 - versus 20-year timeframes (Table 3). We found that the effect of the global warming potential timeframes on $\mathrm{N}_{2} \mathrm{O}$ emissions was interacted with water availability. Under drier conditions, timeframe had no effect on $\mathrm{N}_{2} \mathrm{O}$ emissions or the carbon footprint. Under normal and wetter conditions, however, the results from the two timeframes differed significantly. The estimates from a 20-year timeframe decreased $\mathrm{N}_{2} \mathrm{O}$ emissions by $7.9 \%$, leading to $8.6 \%$ more negative for the net emissions and $8.3 \%$ more negative for the per-yield carbon footprint values, as compared with the 100-year timeframe.

\section{Discussion}

Increasing awareness of climate change and energy security is spurring greater investigation into how farming systems can be better managed to produce high-quality and affordable food in sufficient quantities while minimizing potentially negative impacts on the environment ${ }^{1,3,5}$. The present study demonstrates that each individual farming practice has its own role in affecting crop yield, but that packaging those individually proven farming practices together in a systematic manner can enable an increase in crop yield, while concurrently reducing the carbon footprint of crop production. In the long-term field experiment, we identified and packaged a suite of improved farming practices for spring wheat grown in semiarid rainfed environments, including (i) the choice of crop rotation system, (ii) the use of soil tests to determine soil residual $\mathrm{N}$ and to estimate mineralized $\mathrm{N}$ from soil organic matter that may be available for the crops, (iii) the application of fertilizers to balance the nutrient supplies and plant requirements and (iv) the use of grain legumes to replace the fallow phase of the commonly used 
crop rotations or to diversify the wheat monoculture system. The results of the 25 years of field tests clearly show that wheat crops can be produced with a small or negative carbon footprint if some key farming practices are identified and packaged together at a system level.

Our findings are strongly supported by other studies where improved farming practices increase crop yields without increasing, or even decreasing, carbon emissions. For example, in an UK study, the use of fungicides increased wheat grain yield by $1.78 \mathrm{tha}^{-1}$ and reduced greenhouse gas emissions from 386 to $327 \mathrm{~kg} \mathrm{CO} \mathrm{CO}_{2}$ eq per tonne of grain or by $15 \%$ (ref. 48). In Denmark, with optimized fertilization and improved agronomic practices, winter wheat increased grain yield by $7.9 \%$, whereas greenhouse gas emissions during the production was reduced by $1.7 \mathrm{~g} \mathrm{CO}_{2}$ eq MJ $^{-1}$ of ethanol produced ${ }^{49}$. In Poland, the use of fertilizers selectively from low-carbon emitting manufacturers in wheat production significantly increased the sequestration of soil organic carbon, and reduced carbon emissions by $50 \%$ (ref. 50 ). In New South Wales, Australia, wheat had a carbon footprint value of $0.20 \mathrm{~kg} \mathrm{CO} 2$ eq per $\mathrm{kg}$ of grain on a production level of $3.5 \mathrm{tha}^{-1}$, and the footprint value was reduced to $0.15 \mathrm{~kg} \mathrm{CO}_{2} \mathrm{eq}$ per $\mathrm{kg}$ of grain when the production level was increased to $5.0 \mathrm{tha}^{-1}$, or a $25 \%$ reduction of the $\mathrm{C}$ emissions with the increased yield level ${ }^{40}$.

Our findings are in contrast with many published studies where the production of wheat typically results in positive (undesirable) carbon footprints ${ }^{40,49,51,52}$. In some of those studies, $\mathrm{CO}_{2}$ emissions from crop inputs were substantially greater than was sequestered from the atmosphere ${ }^{51,52}$ or suboptimal farming practices were used (for example, over-fertilizing crops, excessive losses of $\mathrm{N}$ that was unused by the crop), or the various farming practices used were not integrated together effectively. In some studies, soil carbon changes were not assessed in their carbon footprint calculations ${ }^{40,49}$. In a few cases, an incomplete 'life cycle assessment' approach was employed and most importantly the carbon sequestration from the atmosphere back to the soil, a critical component in carbon footprint estimates, was not determined.

In the present study, the choice of cropping systems was a key factor influencing wheat carbon footprints. Use of lentil (a grain legume) to replace the summerfallow phase of the wheat-wheatfallow system reduced the wheat carbon footprint significantly. Based on the fertilizer use in the LentW system (averaging $31.3 \mathrm{~kg} \mathrm{Nha}^{-1}$ ) versus that of wheat monoculture (averaging $44.1 \mathrm{~kg} \mathrm{Nha}^{-1}$ ), we estimated that approximately 0.14 million tonnes of $\mathrm{N}$ fertilizer could be eliminated each year on the Canadian prairie if half of the wheat production areas were established in a legume-cereal rotation system. This switch would lead to an annual reduction of 1.1 million tonnes of greenhouse gas emissions ascribable to crop inputs. This finding does not suggest that any one particular rotation system can be applicable under all situations; however, it is clear that developing and adopting more effective and efficient cropping systems has a key role to play in increasing crop yields while mitigating a significant amount of greenhouse gases in agriculture.

Next was the change of soil organic carbon over time that played a critical role in offsetting carbon emissions associated with crop production inputs. It is well known that the status of carbon in the soil can be influenced by many factors ${ }^{53}$, such as soil texture, environmental conditions, crop management practices and initial soil $\mathrm{C}$ level. The traditional cropping systems used on the semiarid prairies for decades before the initiation of this long-term experiment were mainly fallow-wheat or FWW with little $\mathrm{N}$ fertilizer added to the system. The base value of SOC measured in 1979 when the LentW system was first introduced in the study was about $33 \mathrm{MgCha}^{-1}$ in the $0-15 \mathrm{~cm}$
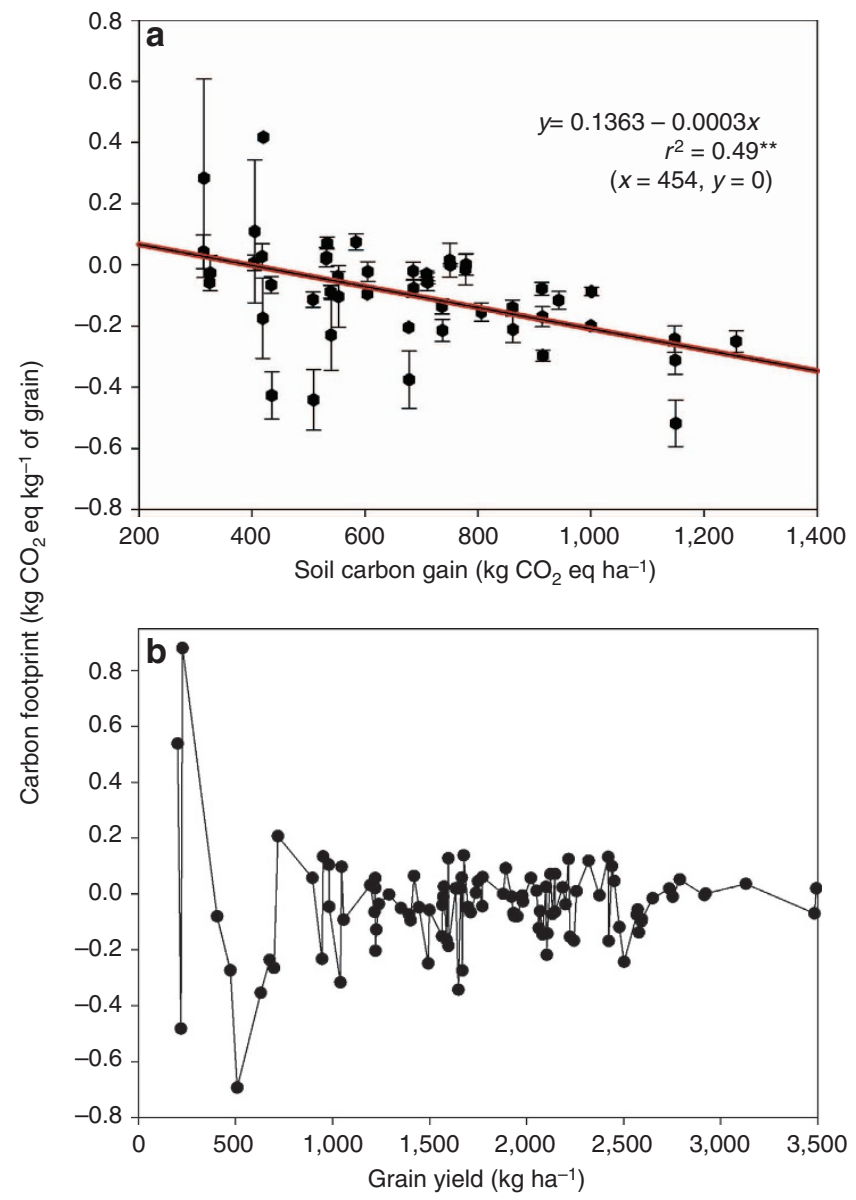

Figure 5 | The relationship between carbon footprint and soil carbon gain and crop yield in wheat. (a) Wheat carbon footprint (with the line bars at the data point being the standard errors) is equal to zero at soil carbon gain of $454 \mathrm{~kg} \mathrm{CO}_{2}$ eq ha $^{-1}$ and it becomes negative (more desirable) with soil carbon gain greater than $454 \mathrm{~kg} \mathrm{CO}_{2}$ eq ha $^{-1}$; and (b) wheat carbon footprint values do not have a clear correlation with the grain yields, even though grain yields serve as the denominator in the calculation of carbon footprint values, suggesting that the carbon footprint of wheat production is an outcome of a complex of various factors.

depth. After the 25 years of the experiment, the SOC level at the field has increased, but it is still substantially lower than they were before the land was cultivated. The conversion of native prairies to agricultural lands has resulted in significant loss of SOC in the soil profile, ultimately leading to the decline of soil fertility in the low-productivity semiarid agroecosystem ${ }^{54}$. It is unknown whether the SOC at the experimental site can be enhanced from the current level, but we speculate that a theoretical potential would be to return the SOC to the level near when the soil was broken for agriculture decades ago. Many recent studies have shown that the change of cropping systems from the traditional frequent fallowing to continuous cropping provides greater carbon input to the soil ${ }^{54}$; the increased $\mathrm{N}$ fertilization also increases crop productivity and the quantity of carbon in the soil ${ }^{55}$. Further, a large portion of plant residue carbon can be sequestered in more stable soil organo-mineral complexes ${ }^{56}$.

However, the quantity of carbon in the soil can decline over time under unfavourable farming practices such as frequent summerfallowing with intensive tillage ${ }^{18}$, low crop yields $s^{27,57}$ with limited amounts of crop residues returned to the soil ${ }^{26}$ or use of sub-optimal farming practices ${ }^{58}$. In the present study, two to five tillage operations were used for weed control during the 


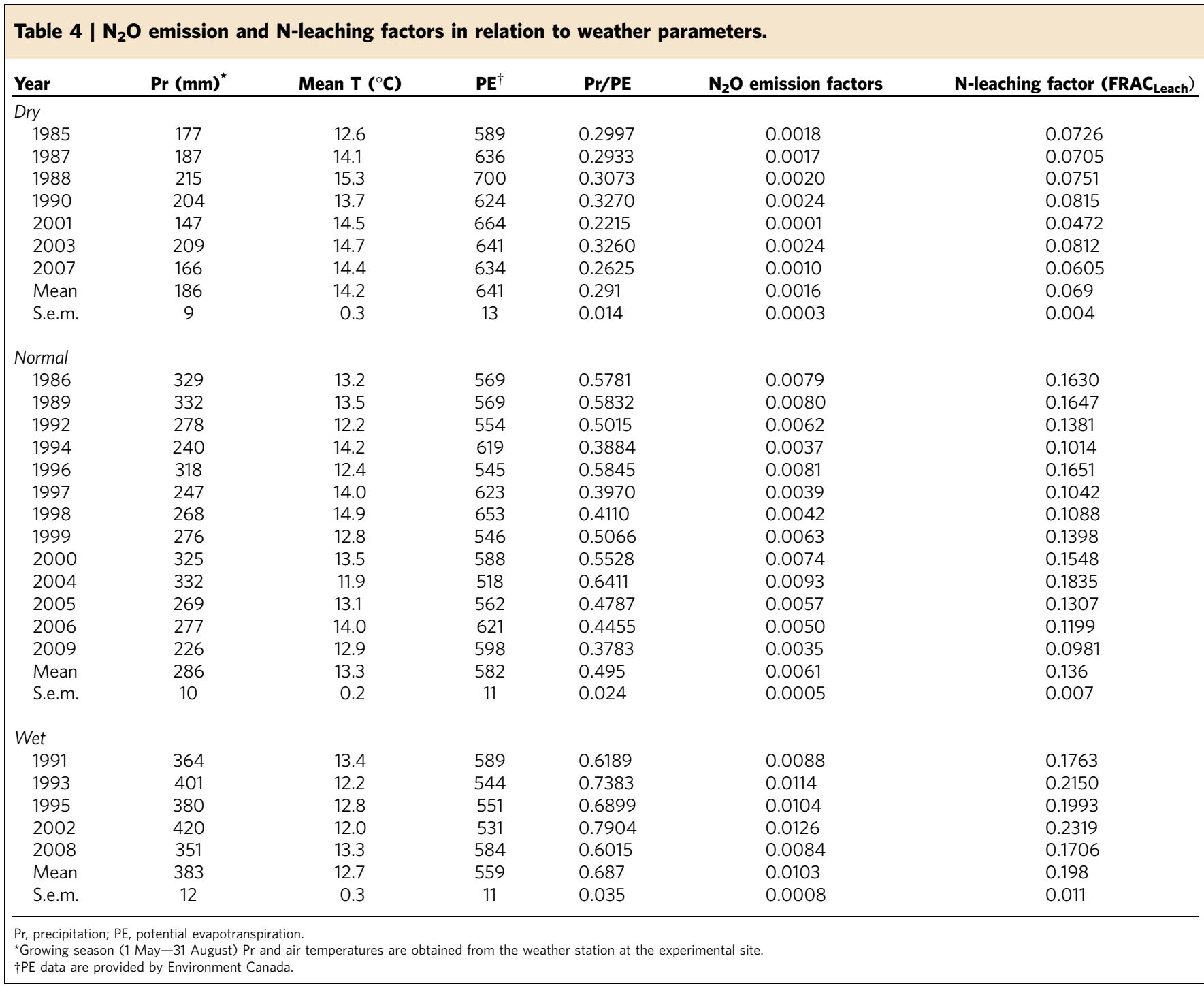

post-harvest fallow period; this may have had negative impacts on soil carbon sequestration as the practice of tilling the soil accelerates the loss of soil carbon ${ }^{28,57}$. Some other studies, however, have shown that tillage can influence mineralizable $\mathrm{C}$ and microbial biomass ${ }^{18}$, but these changes in mineralizable $\mathrm{C}$ do not usually affect crop yields in semiarid climates ${ }^{44}$. It appears that the effect of tillage operation on SOC changes may require a much longer period of time (perhaps several decades ${ }^{18}$ ) to become distinguishable in semiarid climates.

Putting all these together, we acknowledge that the gain in SOC obtained in this long-term experiment may not be indefinite as the SOC accrual may start reaching a new steady state, as evidenced by the fact that the rate of SOC gain in the last decade (that is, the 2000s) has been smaller compared with the earlier decades. Also, the effect of cropping systems on the SOC gain may approach a new equilibrium ${ }^{55}$. Thus, the future implications of SOC on wheat carbon footprints and thus climatic impacts can be complex. If the last decade is really the new normal, the potential climate impact of SOC gain associated with wheat production systems can be small or slightly negative. With many unknown factors involved in this complex issue, we speculate that three possibilities may occur in the future: (i) the carbon footprints may continue to become more negative, as more advanced technologies are adopted in farming practices, with lower-carbon crop inputs being manufactured and used for crop production; (ii) the per-yield carbon footprints may approach zero, with carbon exports equaling carbon imports in wheat production systems, and there may be no net sequestration of carbon or (iii) the per-yield carbon footprint values may trend to be positive, with the slow erosion of the carbon sequestered in the soil with no new carbon sequestration occurring.

Many process-based models have been employed to characterize the trajectories of past crop yields ${ }^{24}$, and to identify possible strategies to continue increasing crop yields ${ }^{25}$ or for closing the yield gaps between the current level and the potential ${ }^{6}$. The added feature from the actual field measurements of our long-term experiment is that one can (i) assess the effect of adopting improved farming practices on crop productivity and their environmental consequences under the highly-variable semiarid climate; (ii) perform a reasonably complete life cycle assessment of wheat production with robust estimates of the carbon footprints and (iii) understand the potential of converting solar radiation to plant biomass and to offset the carbon emissions from the cultivation of natural carbon-rich ecosystems. The production of large-scale staple crops like wheat has been shown to have significant climate consequences. The findings from this well-managed, replicated, long-term field experiment provide strong evidence that spring wheat can be a net carbonsequestering crop with a small or negative carbon footprint, if the crop is produced with the integration of proven farming 
Table 5 | Randomization of different cropping systems and their rotation phases in each replicate.

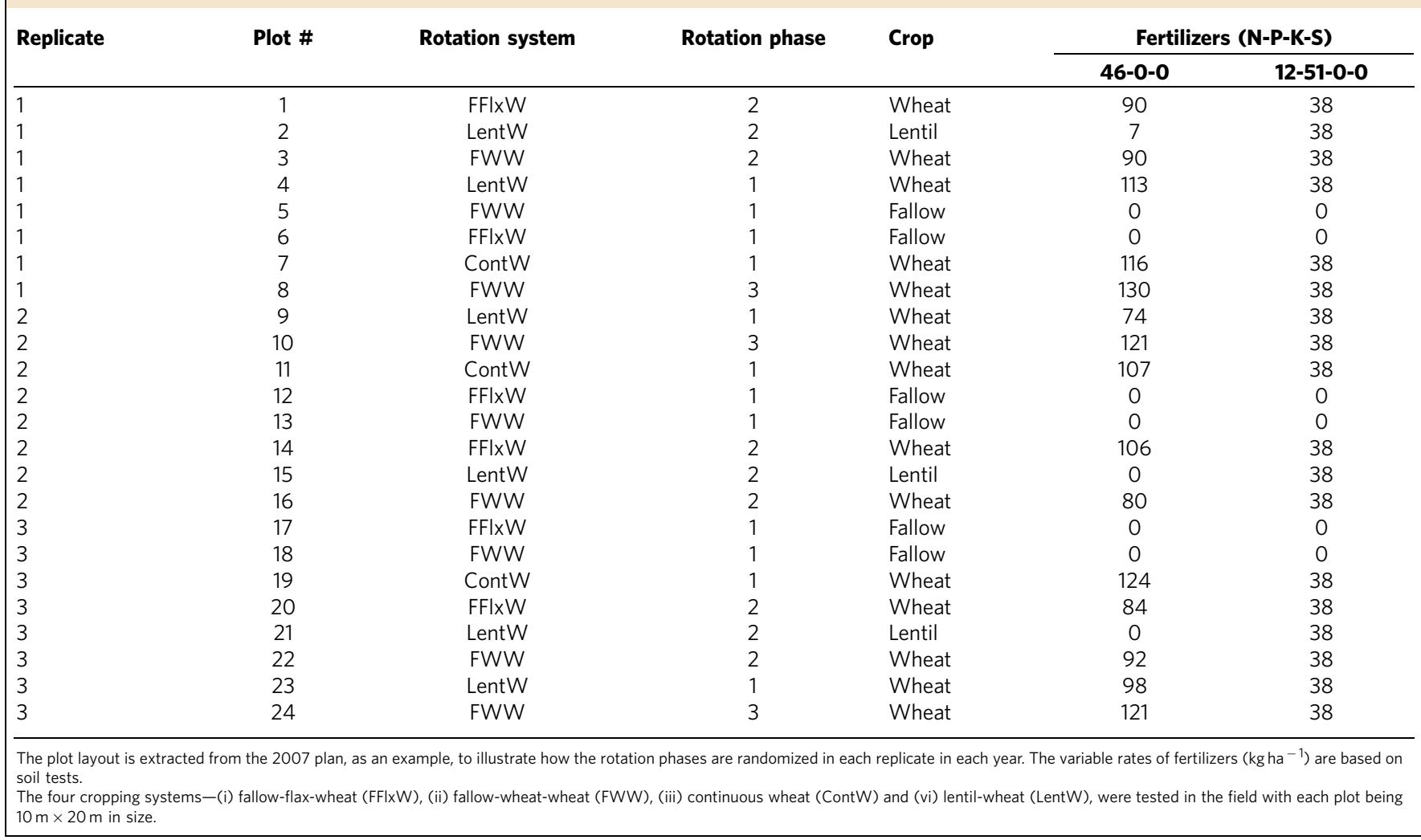

practices. We do not suggest that the net-sequestering goal can be achieved for wheat crops grown in environments different from the semiarid North American prairies, but we do suggest that the production of large-scale staple food crops with advanced farming technologies and practices can increase crop yield, enhance soil carbon sequestration and allow the capture of large society-environmental benefits and other potential co-benefits for human health ${ }^{59}$.

\footnotetext{
Methods

Field plot layout and management. The ContW system had a wheat crop every year; LentW had a wheat crop alternated with a lentil crop every other year; FWW had two wheat crops and summerfallow every 3 years; whereas FFlxW had one wheat crop, one flax crop and summerfallow every 3 years. Agricultural researchers refer to these as 'rotation phases'. So, the ContW system had one phase (that is, wheat every year); LentW had two phases, FWW had three phases and FFlxW had three phases. All these phases were present each year and were randomized in each replicate. Using 2007 as an example, the field plot layout map shows how the various rotations and their phases were randomized in each of the three replicates (Table 5). For example, FWW system had three plots in each replicate: one plot was for phase-1 (FWW), a second plot for phase-2 (FWW) and a third plot for phase-3 (FWW). Thus, for the four rotation systems, there were a total of nine rotation phases that were randomized within each of the three replicates, making a total of 27 plots each year (9 plots per replicate $\times 3$ replicates). All rotations were cycled over the years on their corresponding plots. Each plot was $10 \mathrm{~m}$ by $20 \mathrm{~m}$ in size

In each year, soil $\mathrm{NO}_{3}-\mathrm{N}(0-0.6 \mathrm{~m}$ depth $)$ and soil $\mathrm{P}(0-0.15 \mathrm{~m}$ depth) levels were measured in each plot in fall just before freeze up and these values, along with nutrient application guidelines provided by the Soil Testing Laboratory of the University of Saskatchewan, were used to determine fertilizer rates to be applied in the spring to the following crop. The crops received in-crop weed control as needed using recommended herbicides at label rates. In the fall, 2,4-D was applied to all plots to control winter annual weeds. Plots being planted generally received one preseeding tillage operation with a heavy-duty sweep cultivator and mounted harrow to prepare the seedbed, whereas plots being summerfallowed received two to five tillage operations with a cultivator or rod weeder to control weeds. Full-sized farm equipment was used for all cultural and tillage operations. All the other cropping practices such as planting and harvesting were those recommended for crop production in the local area.
}

Data collection. At full maturity, an area of $2.32 \mathrm{~m}^{2}$ was hand-harvested in each plot for grain and straw biomass, and the six central rows of plants in each plot were combine-harvested for grain yield. The $\mathrm{N}$ concentrations in grain and straw were measured using the standard micro-Kjeldahl method. Root dry weight was estimated using the published model ${ }^{30}$ where root biomass was taken as a proportion of straw biomass, varying with growing conditions. All crop inputs such as seeds, fertilizers, pesticides, fossil fuels and so on were recorded for each of the rotation systems.

Soil organic carbon measured in 1979 (when the LentW rotation was first included in the systems) was used as the starting value or baseline, with subsequent SOC measurements taken in 1981, 1985, 1990, 1993, 1996, 1999, 2003 and 2009 (ref. 55). At each measurement, two soil samples were taken at random within the central part of each plot. The soils were sampled using soil cores with a $5-\mathrm{cm}$ diameter probe, and the cores were then divided into $0-15$ and $15-30 \mathrm{~cm}$ depths. The two cores were bulked within each depth, air dried and sieved $(<2 \mathrm{~mm})$. Representative subsamples of the $<2 \mathrm{~mm}$ soil were ground with a roller mill $(<153 \mu \mathrm{m})$ and a 20 -mg subsample analysed for organic $\mathrm{C}$ with an automated combustion technique (Carlo Erba, Milan, Italy). The organic $\mathrm{C}$ was obtained after pre-treatment of the soil with phosphoric acid to remove inorganic C. The SOC concentrations were converted to weight per volume using soil bulk densities. Annualized SOC gains or losses for each cropping system were calculated using the difference in SOC value at two consecutive measurement dates divided by the number of years between samplings.

Sampling depth is a complex factor. In the semiarid prairies where tillage is usually shallow (no more than $15-20 \mathrm{~cm}$ ), most of the SOC changes occur near the soil surface. Thus, sampling usually is in increments only to the $15-$ or $30-\mathrm{cm}$ soil depth. Typically, absolute differences in SOC among treatments increase with the depth sampled, but statistical significance declines because total mass of $\mathrm{C}$ measured and its variability increase more than the difference among cropping treatments ${ }^{60}$. In fact, significant differences are often observed only in the surface $10 \mathrm{~cm}$ depth, if at all ${ }^{27,61}$. We have therefore confined our discussion on SOC primarily to the changes of SOC in the 0 - to $15-\mathrm{cm}$ soil depth in this experiment. Some more detailed explanations and discussions have been given in previous publications $^{55,61}$ that specifically deal with soil carbon changes found in this longterm field experiment.

Emission estimate and carbon footprint calculation. In the estimate of greenhouse gas emissions, a boundary was set from the manufacture, transportation, storage and delivery of crop inputs (for example, fertilizers and pesticides) to harvest crops $^{51}$. Within the set boundaries, a country-specific approach ${ }^{51,62}$ was used to estimate greenhouse gas emissions from all sources, with site-measured 
data from the semiarid North American prairies 22,45 coupled with empirical modelling ${ }^{62}$. The emissions from energy use and $\mathrm{N}_{2} \mathrm{O}$ emissions from non-energy sources include those from (i) crop residue decomposition, (ii) inorganic $\mathrm{N}$ and phosphorus fertilizer application, (iii) $\mathrm{N}$ losses from leaching and volatilization, (iv) application of herbicides, fungicides and insecticides, (v) fuel used in various farming operations and (vi) fossil energy used in the processes of manufacture, transportation, storage and delivery of fertilizers and pesticides to the farm gate. The emissions of $\mathrm{N}_{2} \mathrm{O}$ and $\mathrm{CH}_{4}$ were converted into $\mathrm{CO}_{2} \mathrm{eq}^{40,51,52}$, which allows the comparison of different cropping systems using the same functional unit.

When a crop is harvested, straw and roots are left in the field to decompose. These crop residues become an important $\mathrm{N}$ source for nitrification and denitrification, contributing directly and indirectly to $\mathrm{N}_{2} \mathrm{O}$ emissions ${ }^{20,63}$. The amount of $\mathrm{N}_{2} \mathrm{O}$ contributed by the decomposition of crop straw and roots is directly related to their $\mathrm{N}$ concentration and biomass yield ${ }^{20}$, thus, straw and root $\mathrm{N}$ concentrations have been incorporated in the emission estimates. The quantity of crop residue $\mathrm{N}$ was obtained using the aboveground and belowground crop residue biomass multiplied by their respective $\mathrm{N}$ concentrations. Thus, $\mathrm{N}_{2} \mathrm{O}$ emissions from farmland are the collective result of $\mathrm{N}$ that has entered the soil from inorganic fertilizers, the decomposition of crop residues, volatilization of $\mathrm{NH}_{3}$ and nitrate losses via leaching and denitrification in wet conditions.

A country-specific model for the determination of $\mathrm{N}_{2} \mathrm{O}$ emission factors for Canadian conditions has been developed and published ${ }^{62}$; this model is primarily based on the actual measurements taken from this Swift Current long-term experiment, along with other related studies ${ }^{22,45}$. Direct emissions from crop residue decomposition, fertilizer $\mathrm{N}$ application and the fraction of $\mathrm{N}$ that is subject to leaching are found to be a function of the ratio of Pr to potential PE:

$$
\mathrm{EF}=0.022 \operatorname{Pr}: \mathrm{PE}-0.0048
$$

$\mathrm{FRAC}_{\text {leach }}=0.3247 \mathrm{Pr}: \mathrm{PE}-0.0247$

where, $\mathrm{EF}$ is the emission factor with a unit of $\mathrm{kg} \mathrm{N}_{2} \mathrm{O}-\mathrm{N} \mathrm{kg}{ }^{-1}$ of N; $\mathrm{Pr} / \mathrm{PE}$ is the ratio of Pr to PE during the growing season and $\mathrm{FRAC}_{\text {leach }}$ is the fraction of fertilizer- and crop residue- $\mathrm{N}$ subject to leaching.

Emissions of $\mathrm{N}_{2} \mathrm{O}$ from inorganic $\mathrm{N}$ fertilizer applications and crop residue decomposition are then estimated as:

$$
\begin{aligned}
\mathrm{CO}_{2} \text { eq }_{\text {snf }}= & Q_{\text {snf }} \times\left\{\left(\mathrm{FRAC}_{\text {gasm }} \times \mathrm{EF}_{\mathrm{vd}}\right)+\mathrm{EF}+\left(\mathrm{FRAC}_{\text {leach }} \times \mathrm{EF}_{\text {leach }}\right)\right\} \\
& \times \frac{44}{28} \times \mathrm{GWP}_{\mathrm{N}_{2} \mathrm{O}} \\
\mathrm{CO}_{2} \mathrm{eq}_{\text {crd }}= & Q_{\text {crd }} \times\left\{\mathrm{EF}+\left(\mathrm{FRAC}_{\text {leach }} \times \mathrm{EF}_{\text {leach }}\right)\right\} \times \frac{44}{28} \times \mathrm{GWP}_{\mathrm{N}_{2} \mathrm{O}}
\end{aligned}
$$

where, $\mathrm{CO}_{2} \mathrm{eq}_{\text {snf }}$ and $\mathrm{CO}_{2} \mathrm{eq}_{\text {crd }}$ are total emissions from the inorganic $\mathrm{N}$ fertilizer application and crop residue decomposition $\left(\mathrm{kg} \mathrm{CO}_{2}\right.$ eq ha $\left.{ }^{-1}\right)$, respectively; $Q_{\text {snf }}$ is the quantity of synthetic $\mathrm{N}$ fertilizer applied $\left(\mathrm{kg} \mathrm{Nha}^{-1}\right) ; Q_{\mathrm{crd}}$ is the quantity of crop residue $\mathrm{N} ; \mathrm{FRAC}_{\mathrm{gasm}}$ is the fraction of inorganic fertilizer- $\mathrm{N}$ that volatilized as $\mathrm{NH}_{3}-$ and $\mathrm{NO}_{\mathrm{x}}-\mathrm{N}\left(\mathrm{FRAC}_{\text {gasm }}=0.1 \mathrm{~kg} \mathrm{~kg}^{-1} \mathrm{~N}\right) ; \mathrm{EF}_{\mathrm{vd}}$ is the $\mathrm{N}_{2} \mathrm{O}$ emission factor for volatilized $\mathrm{NH}_{3}$ - and $\mathrm{NO}_{\mathrm{x}}-\mathrm{N}\left(\mathrm{EF}_{\mathrm{vd}}=0.01 \mathrm{~kg} \mathrm{~N}_{2} \mathrm{O}-\mathrm{N} \mathrm{kg}{ }^{-1} \mathrm{~N}\right)$; $\mathrm{EF}_{\text {leach }}$ is the $\mathrm{N}_{2} \mathrm{O}$ emission factor for nitrate leaching $\left(\mathrm{EF}_{\text {leach }}=0.0075 \mathrm{~kg} \mathrm{~N}_{2} \mathrm{O}-\mathrm{N} \mathrm{kg}^{-1} \mathrm{~N}\right)$; $44 / 28$ is the conversion coefficient from $\mathrm{N}_{2} \mathrm{O}-\mathrm{N}$ to $\mathrm{N}_{2} \mathrm{O}$ and the $\mathrm{GWP}_{\mathrm{N} 2 \mathrm{O}}=298$ for the global warming potential of $\mathrm{N}_{2} \mathrm{O}$ for the 100-year timeframe and the $\mathrm{GWP}_{\mathrm{N} 2 \mathrm{O}}=268$ for the 20 -year timeframe ${ }^{64}$

In our presentation, the calculations of carbon footprint are primarily based on the global warming potential in a time horizon of 100 years as this is the recommendation by the IPCC and is used by regulators ${ }^{47}$. However, to assess the potential usefulness for overall policy relevance, we also calculated the carbon footprint values using $\mathrm{GWP}_{\mathrm{N} 2 \mathrm{O}}=268$ for the 20 -year timeframe in converting $\mathrm{N}_{2} \mathrm{O}$ to $\mathrm{CO}_{2}$ equivalents. The comparison between the two sets of calculations may give some indications about the sensitivity of the results to the choice of timeframe and help us to understand the shorter- versus longer-term benefits. This effort is based on the understanding that global warming potential is a relative measure of how much heat a greenhouse gas traps in the atmosphere ${ }^{65}$.

Although having all $\mathrm{N}_{2} \mathrm{O}$ emission estimates based on field measurements would be ideal, such long-term data sets do not exist. The estimates in the present study were based on a well-scrutinized method ${ }^{62}$ that utilized measured data from the long-term experiment and other relevant studies. The emission estimates in the present study compared well to those field-measurements from the specific rotation systems discussed previously ${ }^{22,45}$, and those from similar studies of comparable systems ${ }^{66}$.

Herbicides, fungicides and insecticides were used as needed and at recommended rates in the experiment. In the emission estimates, we used average emission factors of $23.2 \mathrm{~kg} \mathrm{CO}_{2} \mathrm{eq} \mathrm{kg}^{-1}$ of active ingredient for herbicides and $13.8 \mathrm{~kg} \mathrm{CO}_{2} \mathrm{eq} \mathrm{kg}^{-1}$ of active ingredient for fungicides and insecticides. These emission factors were based on the estimates of fossil energy use during the processes of manufacture, transportation, storage and delivery of the products to the farm gate. The total emissions associated with the use of pesticides were calculated by multiplying the emission factors with the quantity of the pesticides actually applied to the crops in each rotation system. The resulting values are in the range published by others from the North American prairies ${ }^{22,51,67}$, and areas of the semiarid Australia with production systems similar to ours ${ }^{40}$. Although the true emission values for individual pesticides may differ from those calculated using our constant factors, the relative values are believed to be reasonable given that the portion of the overall carbon footprint contributed by pesticides under dryland conditions is generally small ${ }^{37,48,51}$.

The emissions associated with miscellaneous farming operations such as planting, applying pesticides and harvesting were estimated using a factor of $14 \mathrm{~kg}$ $\mathrm{CO}_{2}$ eq ha ${ }^{-1}$ for planting, $5 \mathrm{~kg} \mathrm{CO}_{2} \mathrm{eq} \mathrm{ha}^{-1}$ for pesticide application and $37 \mathrm{~kg}$ $\mathrm{CO}_{2}$ eq ha ${ }^{-1}$ for harvesting. These emission factors are also in the range of the values published by others for the North American prairies $22,36,37,68$.

Finally, summerfallow is a farming practice typically used in the arid and semiarid prairies to control weeds through tillage and to conserve soil moisture by leaving the land unplanted for an entire growing season. The $\mathrm{N}_{2} \mathrm{O}$ emissions during the summerfallow period were estimated based on the actual inputs (such as fuel use in tillage operations) plus indirect emissions from non-input sources such as residual soil $\mathrm{N}$ and the decomposition of organic matter present in the soil ${ }^{62}$; the latter portion was to account for these emissions not captured by the input-based method $^{22,45}$.

Statistical analysis. To avoid the confounding effect of highly variable growing season precipitation on the treatments, we categorized the 25 (1985-2009) experimental years into three water-availability conditions: dry, normal and wet (Table 4). In 7 dry years, growing season (1 May to 31 August) Pr averaged $186 \mathrm{~mm}, \mathrm{PE} 641 \mathrm{~mm}(\operatorname{Pr}$ to $\mathrm{PE}$ ratio $=0.291)$ and mean air temperature $14.2^{\circ} \mathrm{C}$. In 5 wet years, the $\operatorname{Pr}$ averaged $383 \mathrm{~mm}, \mathrm{PE} 559 \mathrm{~mm}(\mathrm{Pr} / \mathrm{PE}=0.687)$ and mean air temperature $12.7^{\circ} \mathrm{C}$. The remaining 13 years had weather conditions near the longterm means, with $\mathrm{Pr}$ averaging $286 \mathrm{~mm}, \mathrm{PE} 582 \mathrm{~mm}(\mathrm{Pr} / \mathrm{PE}=0.496)$ and air temperature $13.3^{\circ} \mathrm{C}$.

All phases of each rotation were present every year and randomized in each replicate; this allowed the analysis to be performed on a complete rotation basis. We determined all variables (for example, production inputs, crop yields, $\mathrm{C}$ emissions and so on) for the complete rotation systems (that is, all phases in each year) and then converted the results into annualized values. For example, the annualized grain yield for the FWW system in replicate I in 2007 (Table 5) was the sum of the yields from three plots (plot \#3, \#5, \#8) divided by 3 (zero yield in plot $\# 5$, the fallow phase). Thus, the individual years were considered independent in the statistical analyses. There were 7 dry years, 13 normal years and 5 wet years, with three replicates in each year; the mixed effect model gives the best results for the least significant differences between the four rotation systems, with random effects being: $3 \times 7,3 \times 13$ and $3 \times 5$ in dry, normal and wet years, respectively ${ }^{69}$

Preliminary analysis revealed significant interactions between cropping systems and water-availability categories (dry, normal and wet) for most of the variables assessed, therefore, treatment effects were primarily discussed for each of the three water-availability categories. Means and standard errors of the means were estimated on the basis of three replicates per year $\times$ the number of years in each water-availability category $(n=3 \times 7,3 \times 13$ and $3 \times 5$ in dry, normal and wet years, respectively). Regressions were used to determine the relationships between grain yield and precipitation, between $\mathrm{N}$ input and greenhouse gas emissions, between $\mathrm{N}$ input and $\mathrm{N}$ uptake by plants, and between $\mathrm{N}$ input and $\mathrm{N}$-surplus. An analysis of covariance was used to determine the relative contribution of various crop input factors to the carbon footprint values ${ }^{69,70}$

Finally, sensitivity tests were conducted to assess how sensitive the $\mathrm{N}_{2} \mathrm{O}$ emission profiles and the resulting carbon footprints are to (i) the methods of $\mathrm{N}$ fertilizer application; (ii) the level of SOC gain or loss over years and (iii) the estimates of carbon footprints based on the 100- versus 20-year timeframes of global warming potential.

\section{References}

1. Tilman, D., Balzer, C., Hill, J. \& Befort, B. L. Global food demand and the sustainable intensification of agriculture. Proc. Natl Acad. Sci. USA 108, 20260-20264 (2011).

2. Fedoroff, N. V. et al. Radically rethinking agriculture for the 21 st century. Science 327, 833-834 (2010).

3. Godfray, H. C. J. et al. Food security: the challenge of feeding 9 billion people. Science 327, 812-818 (2010).

4. Foley, J. A. et al. Solutions for a cultivated planet. Nature 478, 337-342 (2011).

5. Garnett, T. et al. Sustainable intensification in agriculture: premises and policies. Science 341, 33-34 (2013).

6. Mueller, N. D. et al. Closing yield gaps through nutrient and water management. Nature 490, 254-257 (2012).

7. FAOSTAT. FAO. Statistical Yearbooks-World food and agriculture. Food Agric. Organizat. United Nations 2013, 288 pp (2014).

8. Mikha, M. M., Vigila, M. F. \& Benjamina, J. G. Long-term tillage impacts on soil aggregation and carbon dynamics under wheat-fallow in the central Great Plains. Soil Water Manage. Conserv 77, 594-605 (2013).

9. Lafond, G., McConkey, B. G. \& Stumborg, M. Conservation tillage models for small-scale farming: linking the Canadian experience to the small farms of Inner Mongolia Autonomous Region in China. Soil Tillage Res. 104, 150-155 (2009). 
10. Maraseni, T. N. \& Cockfield, G. Does the adoption of zero tillage reduce greenhouse gas emissions? An assessment for the grains industry in Australia. Agri. Syst. 104, 451-458 (2011).

11. Hou, X. Q. et al. Effects of rotational tillage practices on soil structure, organic carbon concentration and crop yields in semi-arid areas of northwest China. Soil Use Manage. 28, 551-558 (2012).

12. Borontov, O. K., Nikul'nikov, I. M., Kurakov, V. I. \& Sumin, A. N. The waterphysical properties and water regime of leached chernozems under different tillage and fertilization practices in crop rotation. Eurasian Soil Sci. 38, 103-110 (2005).

13. Nyamadzawo, G., Nyamangara, J., Nyamugafata, P. \& Muzulu, A. Soil microbial biomass and mineralization of aggregate protected carbon in fallowmaize systems under conventional and no-tillage in Central Zimbabwe. Soil Tillage Res. 102, 151-157 (2009).

14. Sun, M. et al. Effect of subsoiling in fallow period on soil water storage and grain protein accumulation of dryland wheat and its regulatory effect by nitrogen application. PLoS One 8, e75191 (2013).

15. Hunt, J. R. et al. Summer fallow weed control and residue management impacts on winter crop yield though soil water and $\mathrm{N}$ accumulation in a winterdominant, low rainfall region of southern Australia. Crop Pasture Sci. 64, 922-934 (2013).

16. Campbell, C. A. et al. Nitrogen mineralization under summer fallow and continuous wheat in the semiarid Canadian prairie. Can. J. Soil Sci. 88, 681-696 (2008).

17. Campbell, C. A. et al. Effect of crop rotation, fertilizer and tillage management on spring wheat grain yield and $\mathrm{N}$ and $\mathrm{P}$ content in a thin Black Chernozem: a long-term study. Can. J. Plant Sci. 91, 467-483 (2011).

18. Shrestha, B. M. et al. Effects of crop rotation, crop type and tillage on soil organic carbon in a semiarid climate. Can. J. Soil Sci. 93, 137-146 (2013).

19. Dyer, J. A. \& Desjardins, R. L. A review and evaluation of fossil energy and carbon dioxide emissions in Canadian agriculture. J. Sustain. Agric. 33, 210-228 (2009)

20. Janzen, H. H. et al. A proposed approach to estimate and reduce net greenhouse gas emissions from whole farms. Can. J. Soil Sci. 86, 401-418 (2006).

21. Campbell, C. A. et al. Long-term effect of cropping system and nitrogen and phosphorus fertilizer on production and nitrogen economy of grain crops in a Brown Chernozem. Can. J. Plant Sci. 85, 81-93 (2005).

22. Dusenbury, M. P., Engel, R. E., Miller, P. R., Lemke, R. L. \& Wallander, R. Nitrous oxide emissions from a northern great plains soil as influenced by nitrogen management and cropping systems. J. Environ. Qual. 37, 542-550 (2008).

23. Guo, J. H. et al. Significant acidification in major chinese croplands. Science 327, 1008-1010 (2010).

24. Grassini, P., Eskridge, K. M. \& Cassman, K. G. Distinguishing between yield advances and yield plateaus in historical crop production trends. Nat. Commun. 4, 2918 (2013).

25. Ray, D. K., Ramankutty, N., Mueller, N. D., West, P. C. \& Foley, J. A. Recent patterns of crop yield growth and stagnation. Nat. Commun. 3, 1293 (2012).

26. Gan, Y. T., Liang, B. C., Liu, L. P., Wang, X. Y. \& McDonald, C. L. C:N ratios and carbon distribution profile across rooting zones in oilseed and pulse crops. Crop Pasture Sci. 62, 496-503 (2011).

27. Campbell, C. A. et al. Organic C accumulation in soil over 30 years in semiarid southwestern Saskatchewan-Effect of crop rotations and fertilizers. Can. J. Soil Sci. 80, 179-192 (2000).

28. Chivenge, P. P., Murwira, H. K., Giller, K. E., Mapfumo, P. \& Six, J. Long-term impact of reduced tillage and residue management on soil carbon stabilization: implications for conservation agriculture on contrasting soils. Soil Till. Res. 94, 328-337 (2007)

29. Smith, W. N. et al. Crop residue removal effects on soil carbon: Measured and inter-model comparisons. Agr. Ecosyst. Environ. 161, 27-38 (2012).

30. Gan, Y. T. et al. Carbon input to soil from oilseed and pulse crops on the Canadian prairies. Agr. Ecosyst. Environ. 132, 290-297 (2009).

31. Jensen, E. S. et al. Legumes for mitigation of climate change and the provision of feedstock for biofuels and biorefineries. A review. Agron. Sustain. Dev. 32, 329-364 (2012)

32. Gan, Y., Campbell, C. A., Liu, L., Basnyat, P. \& McDonald, C. L. Water use and distribution profile under pulse and oilseed crops in semiarid northern high latitude areas. Agr. Water Manage. 96, 337-348 (2009).

33. Campbell, C. A. et al. Water use efficiency and water and nitrate distribution in soil in the semiarid prairie: effect of crop type over 21 years. Can. J. Plant Sci. 87, 815-827 (2007).

34. Selles, F. et al. Phosphorus use efficiency and long-term trends in soil available phosphorus in wheat production systems with and without nitrogen fertilizer. Can. J. Soil Sci. 91, 39-52 (2011).

35. van Groenigen, J. W., Velthof, G. L., Oenema, O., Van Groenigen, K. J. \& Van Kessel, C. Towards an agronomic assessment of N2O emissions: a case study for arable crops. Eur. J. Soil Sci. 61, 903-913 (2010)
36. Gan, Y. et al. Carbon footprint of spring wheat in response to fallow frequency and soil carbon changes over 25 years on the semiarid Canadian prairie. Eur. J. Agron. 43, 175-184 (2012).

37. Lal, R. Carbon emission from farm operations. Environ. Intl. 30, 981-990 (2004).

38. West, P. C. et al. Trading carbon for food: Global comparison of carbon stocks vs. crop yields on agricultural land. Proc. Natl Acad. Sci. USA 107, 19645-19648 (2010).

39. Rajaniemi, M., Mikkola, H. \& Ahokas, J. Greenhouse gas emissions from oats barley, wheat and rye production. Agron. Res 9, 189-195 (2011).

40. Brock, P., Madden, P., Schwenke, G. \& Herridge, D. Greenhouse gas emissions profile for 1 tonne of wheat produced in Central Zone (East) New South Wales: A life cycle assessment approach. Crop Pasture Sci. 63, 319-329 (2012).

41. Berry, P. M., Kindred, D. R., Olesen, J. E., Jorgensen, L. N. \& Paveley, N. D. Quantifying the effect of interactions between disease control, nitrogen supply and land use change on the greenhouse gas emissions associated with wheat production. Plant Pathol. 59, 753-763 (2010).

42. Li, H. et al. Modelling impacts of alternative farming management practices on greenhouse gas emissions from a winter wheat-maize rotation system in China Agr. Ecosyst. Environ. 135, 24-33 (2010).

43. Mooshammer, M. et al. Adjustment of microbial nitrogen use efficiency to carbon:Nitrogen imbalances regulates soil nitrogen cycling. Nat. Commun. 5, 1-7 (2014)

44. Campbell, C. A. et al. Carbon storage in soils of the North American Great Plains: Effect of cropping frequency. Agron. J. 97, 349-363 (2005).

45. Lemke, R. L., Zhong, Z., Campbell, C. A. \& Zentner, R. Can pulse crops play a role in mitigating greenhouse gases from North American agriculture? Agron. J. 99, 1719-1725 (2007).

46. Gan, Y. T. et al. Influence of diverse cropping sequences on durum wheat yield and protein in the semiarid northern Great Plains. Agron. J. 95, 245-252 (2003).

47. Myhre, G. et al. in Climate Change 2013: The Physical Science Basis. Contribution of Working Group I to the Fifth Assessment Report of the Intergovernmental Panel on Climate Change. (eds Stocker, T. F., Qin, D., Plattner, G.-K., Tignor, M., Allen, S. K., Boschung, J., Nauels, A., Xia, Y., Bex, V. \& Midgley, P. M.) (Cambridge University Press, 2013).

48. Berry, P. M., Kindred, D. R. \& Paveley, N. D. Quantifying the effects of fungicides and disease resistance on greenhouse gas emissions associated with wheat production. Plant Pathol. 57, 1000-1008 (2008).

49. Elsgaard, L., Olesen, J. E., Hermansen, J. E., Kristensen, I. T. \& Børgesen, C. D. Regional greenhouse gas emissions from cultivation of winter wheat and winter rapeseed for biofuels in Denmark. Acta Agri. Scandinavica Section B Soil Plant Sci. 63, 219-230 (2013)

50. Syp, A., Jarosz, Z., Faber, A., Borzecka-Walker, M. \& Pudełko, R. Greenhouse gas emissions from winter wheat cultivation for bioethanol production in Poland. J. Food Agri. Environ. 10, 1169-1172 (2012).

51. Gan, Y., Liang, C., Hamel, C., Cutforth, H. \& Wang, H. Strategies for reducing the carbon footprint of field crops for semiarid areas. A review. Agron. Sustain. Dev. 31, 643-656 (2011).

52. Wiedmann, T. et al. Carbon footprint time series of the UK-results from a multi-region input-output model. Econ. Syst. Res. 22, 19-42 (2010).

53. Tan, W. F. et al. Soil inorganic carbon stock under different soil types and land uses on the Loess Plateau region of China. Catena 121, 22-30 (2014).

54. Hurisso, T. T., Norton, J. B. \& Norton, U. Soil profile carbon and nitrogen in prairie, perennial grass-legume mixture and wheat-fallow production in the central High Plains, USA. Agr. Ecosyst. Environ. 181, 179-187 (2013).

55. Campbell, C. A. et al. Quantifying carbon sequestration in a minimum tillage crop rotation study in semiarid southwestern Saskatchewan. Can. J. Soil Sci. 87, 235-250 (2007)

56. Hoyle, F. C., D’Antuono, M., Overheu, T. \& Murphy, D. V. Capacity for increasing soil organic carbon stocks in dryland agricultural systems. Soil Res 51, 657-667 (2013).

57. Malhi, S. S. et al. Long-term straw management and $\mathrm{N}$ fertilizer rate effects on quantity and quality of organic $\mathrm{C}$ and $\mathrm{N}$ and some chemical properties in two contrasting soils in Western Canada. Biol. Fert. Soils 47, 785-800 (2011).

58. Yang, X., Gao, W., Zhang, M., Chen, Y. \& Sui, P. Reducing agricultural carbon footprint through diversified crop rotation systems in the North China Plain. J. Cleaner Prod 76, 131-139 (2014).

59. West, J. J. et al. Co-benefits of mitigating global greenhouse gas emissions for future air quality and human health. Nat. Climate Change 3, 885-889 (2013).

60. Ellert, B. H., Janzen, H. H. \& Entz, T. Assessment of a method to measure temporal change in soil carbon storage. Soil Sci. Soc. Am. J. 66, 1689-1695 (2002).

61. Lemke, R. L., VandenBygaart, A. J., Campbell, C. A., Lafond, G. P. \& Grant, B. Crop residue removal and fertilizer $\mathrm{N}$ : effects on soil organic carbon in a long-term crop rotation experiment on a Udic Boroll. Agr. Ecosyst. Environ. 135, 42-51 (2010). 
62. Rochette, P. et al. Estimation of $\mathrm{N}_{2} \mathrm{O}$ emissions from agricultural soils in Canada. I. Development of a country-specific methodology. Can. J. Soil Sci. 88, 641-654 (2008).

63. Robertson, G. P., Paul, E. A. \& Harwood, R. R. Greenhouse gases in intensive agriculture: contributions of individual gases to the radiative forcing of the atmosphere. Science 289, 1922-1925 (2000).

64. IPCC. IPCC Guidelines for National Greenhouse Gas Inventories. Institute for Global Environmental Strategies, Kamiyamaguchi, Hayama, Kanagawa, Japan (2006).

65. Sathre, R. Comparing the heat of combustion of fossil fuels to the heat accumulated by their lifecycle greenhouse gases. Fuel 115, 674-677 (2014).

66. Mosier, A. R., Halvorson, A. D., Reule, C. A. \& Liu, X. J. Net global warming potential and greenhouse gas intensity in irrigated cropping systems in northeastern Colorado. J. Environ. Qual. 35, 1584-1598 (2006).

67. Lal, R. Soils and sustainable agriculture. A review. Agron. Sustain. Dev. 28, 57-64 (2008).

68. Kinney, C. A., Mosier, A. R., Ferrer, I., Furlong, E. T. \& Mandernack, K. W. Effects of the fungicides mancozeb and chlorothalonil on fluxes of $\mathrm{CO}_{2}, \mathrm{~N}_{2} \mathrm{O}$, and $\mathrm{CH}_{4}$ in a fertilized Colorado grassland soil. J. Geophys. Res. 109 D05303 $1-15$ (2004).

69. Yang, R. C. Towards understanding and use of mixed-model analysis of agricultural experiments. Can. J. Plant Sci. 90, 605-627 (2010).

70. Zentner, R. P. et al. Effect of fallow frequency, flexible rotations, legume green manure, and wheat class on the economics of wheat production in the Brown soil zone. Can. J. Plant Sci. 86, 413-423 (2006).

\section{Acknowledgements}

We acknowledge Kelsey Brandt, Barry Blomert, Darrell Hahn, Duaine Messer, Rod Ljunggren, Doug Judiesch, Dean James, Don Sluth, Evan Powell, Keith Hanson and Ken Deobald for technical assistance, and the financial support from Agriculture and
Agri-Food Canada, Environmental Canada, Saskatchewan Pulse Growers, National Natural Science Foundation of China (31360323), the Excellent Youth Foundation of Gansu Scientific Committee (1111RJDA006), the National Key Technology R\&D Program (2012BAD14B10) and the Outstanding Talent Culture Project of Gansu Agricultural University.

\section{Authors contributions}

Y.G., C.L. and Q.C. conceived the study and constructed the models; Q.C and Y.G. performed the statistical analyses; R.L.L., C.A.C. and R.P.Z are involved in field data collection; all authors contributed to writing the paper.

\section{Additional information}

Supplementary Information accompanies this paper at http://www.nature.com/ naturecommunications

Competing financial interests: The authors declare no competing financial interests

Reprints and permission information is available online at http://npg.nature.com/ reprintsandpermissions/

How to cite this article: Gan, Y. et al. Improving farming practices reduce the carbon footprint of spring wheat production. Nat. Commun. 5:5012 doi: 10.1038/ncomms6012 (2014).

(c) (i) This work is licensed under a Creative Commons Attribution 4.0 International License. The images or other third party material in this article are included in the article's Creative Commons license, unless indicated otherwise in the credit line; if the material is not included under the Creative Commons license, users will need to obtain permission from the license holder to reproduce the material. To view a copy of this license, visit http://creativecommons.org/licenses/by/4.0/ 